\title{
Evaluación de las propiedades físicas de dos rocas carbonáticas usadas como material de construcción actual e histórico en Andalucía Oriental, España
}

\section{Physical properties of carbonate rocks used as a modern and historic construction material in Eastern Andalusia, Spain}

\author{
M. Urosevic(*), E. Sebastián Pardo(*), E. Ruiz-Agudo(*), C. Cardell(*)
}

Recepción/Received: 15-VII-09

Aceptación/Accepted: 22-III-10

Publicado online/Online publishing: 09-IV-10

\section{RESUMEN}

Se han caracterizado dos rocas carbonáticas de Andalucía Oriental; la calcarenita de Escúzar de Granada y el travertino Olivillo de Alhama de Almería. Ambas podrían reemplazar a dos materiales del patrimonio arquitectónico de Andalucía, la calcarenita La Escribana y el travertino Alfacar ambos de Granada. Los materiales mencionados se estudiaron mediante difracción y fluorescencia de rayos $\mathrm{X}$, microscopías óptica y electrónica de barrido, ensayos hídricos, porosimetría de mercurio, adsorción de gases, pulsos ultrasónicos y parámetros cromáticos. La calcarenita Escúzar presenta grandes poros y una porosidad abierta y área superficial superior a la calcarenita $L a$ Escribana; el cromatismo de ambas es similar. El travertino Olivillo es una roca masiva poco porosa. Las propagaciones de ultrasonidos son homogéneas y elevadas, traduciéndose en excelentes propiedades mecánicas. Sin embargo, sus marcadas diferencias hídricas y cromáticas respecto al travertino Alfacar reducen su idoneidad como material sustitutivo de éste en el patrimonio arquitectónico.

Palabres clave: calcarenita, travertino, rocas ornamentales, propiedades físicas, porosimetría de mercurio.

\section{SUMMARY}

We present a detailed characterization of two calcareous stones from Andalusia (Southern Spain), namely Escúzar calcarenite and Olivillo travertine. Both materials can replace two stones extensively used in the architectural heritage of Andalusia, i.e. La Escribana calcarenite and Alfacar travertine. To establish the suitability of the replacement of ancient materials, detailed examination was performed. $X$-ray diffraction, $X$-ray fluorescence, optical and scanning electron microscopy, hydric tests, mercury intrusion porosimetry, gas adsorption, ultrasounds and colorimetry were applied. The Escúzar calcarenite has large pore cavities and higher open porosity than La Escribana calcarenite. From a chromatic point of view both calcarenites are rather similar. The Olivillo travertine is a massive well cemented and heterogeneously colored rock. The ultrasounds velocities for this material are very homogeneous and elevated, indicating excellent mechanical properties. However the hydric and chromatic differences between both travertines point to reduced adequacy of Olivillo travertine as substitutive material for Alfacar.

Keywords: calcarenite, travertine, ornamental rocks, physical properties, mercury porosimetry.

(*) Universidad de Granada (Granada, España). 


\section{INTRODUCCIÓN}

A diferencia de otras regiones de España, donde la mayor parte del patrimonio monumental está constituido por rocas plutónicas (principalmente graníticas), el contexto geológico de Andalucía Oriental ha propiciado el uso frecuente de rocas carbonáticas a lo largo de toda su historia arquitectónica $(1,2)$. Aunque la composición mineralógica de las rocas carbonáticas es relativamente simple, las variedades litológicas existentes pueden ser muy amplias como consecuencia de una variación extensa de texturas y estructuras sedimentarias. Esta variabilidad se refleja en una gran dispersión en los valores de sus propiedades físicas (3-10) que determinan el uso de estos materiales como elementos constructivos $(9,11,12)$. Por lo tanto, pequeñas variaciones texturales pueden producir cambios significativos en las propiedades físicas de los materiales pétreos, modificando así su idoneidad como material arquitectónico (13). Estas variaciones texturales tienen lugar entre diferentes canteras que explotan un mismo material, por lo que las propiedades físicas deben ser evaluadas en cada una de las zonas extractivas.

La piedra de sustitución debe cumplir una serie de requisitos de idoneidad y compatibilidad con la piedra original existente en el monumento, como características petrofísicas y aspecto exterior (13). No obstante, es interesante que la piedra empleada en la restauración presente un cromatismo diferente a la que sustituye, aunque el contraste cromático no debe ser muy acentuado puesto que induciría al deterioro estético del monumento.

Existen una serie de aspectos que dificultan el uso de la piedra natural en intervenciones de sustitución en el patrimonio arquitectónico. Entre otros, cabe mencionar la ausencia de artesanos de la cantería, una sociedad competitiva que induce el uso de materiales de menor coste (como materiales artificiales que imitan a la piedra natural), el cierre de las canteras originales, su inutilización por encontrarse en zonas urbanas, parques naturales protegidas, o su baja rentabilidad (13).

La frecuente disminución de la rentabilidad económica a medida que avanza el frente de extracción en canteras provoca el cierre de las labores, o su desplazamiento a otras zonas cercanas con unas mejores condiciones de explotación. Tal es el caso de dos canteras que han proporcionado gran cantidad de piedras ampliamente utilizados en el patrimonio arquitectónico de Andalucía Oriental: (a) la cantera de calcarenita de La Escribana y (b) la cantera de travertino de Alfacar, ambas en la provincia de Granada (España) y muy cercanas a la capital.

Un ejemplo significativo del desplazamiento a una zona extractiva con mejores condiciones económicas de explotación lo constituye la cantera de La Escribana, que

\section{INTRODUCTION}

While in other regions of Spain most of the monumental heritage is based on plutonic rock (primarily granite), the geological context of Eastern Andalusia favoured the frequent use of carbonate rock throughout its architectural history $(1,2)$. Although the mineralogical composition of carbonate rocks is relatively simple, a wide range of lithological varieties can be identified as a result of differences in texture and sedimentary structure. This variability is reflected in the dispersion of the values of the physical properties (3-10) that determine the aptness of these materials for use in construction $(9,11,12)$. Consequently, minor textural variations may lead to significant changes in the physical properties of such stone, modifying its usability as an architectural material (13). Since these textural variations are found between quarries exploiting the same rock, the physical properties of each material extracted must be assessed separately.

Replacement stone must be suitable for the monument to be restored and compatible with the original stone, in terms of both its petrophysical characteristics and outer appearance (13). Nonetheless, the stone used in restoration work should be chromatically different from the stone replaced, although this contrast should be moderate only so as not to detract from the aesthetics of the monument.

A number of factors render the use of natural stone as a replacement material in heritage structures somewhat difficult. These include the shortage of quarrymen, a competitive society that induces the use of lower cost materials (specifically, artificial materials that imitate natural stone), the closure or non-usability of the original quarries due to their location in urban areas or protected natural parks or their scant profitability (13).

The frequent decline in profitability as the extraction front advances prompts quarry closure or relocation to nearby areas where the operating conditions are more advantageous. This is the case of two quarries that supplied a large amount of stone widely used in the architectural heritage of Eastern Andalusia: the La Escribana calcarenite and the Alfacar travertine quarries, both in the Spanish province of Granada, very close to the provincial capital.

La Escribana constitutes a typical example of relocation to a more profitable extraction area. Until its closure in 1994 it supplied one of the construction materials most 
proporcionó hasta su cierre en 1994 uno de los materiales de construcción más utilizados en las edificaciones monumentales de Granada. La calcarenita denominada "Piedra Franca" extraída de la cantera de La Escribana (en el Cortijo Santa Pudia) se ha utilizado, por ejemplo, en la Catedral de Granada, el Palacio de Carlos V, el Monasterio de San Jerónimo, el Hospital Real y la Real Chancillería (3, 14-16). Tras el cierre de La Escribana, las actividades extractivas fueron desplazadas a la cantera de Escúzar, también conocida como Las Parideras e igualmente situada en el Cortijo Santa Pudia, en la que se han seguido explotando calcarenitas utilizadas recientemente en la restauración de la Mezquita de Córdoba o el Palacio de las Cinco Llagas de Sevilla (actual sede del Parlamento de Andalucía).

Un segundo ejemplo, escasamente estudiado, lo constituyen los travertinos que se explotaban en las canteras de Alfacar, que suministraron material para la construcción del Monasterio de San Jerónimo, el Hospital Real, la Iglesia de San Justo y Pastor o la Iglesia del Salvador (14-19). Los travertinos de Alfacar han sido sustituidos por los explotados en numerosas canteras de la provincia de Almería (Andalucía Oriental), como el travertino de Albox o el de Alhama de Almería.

El objetivo de este trabajo es la caracterización de las nuevas variedades pétreas mencionadas, como la calcarenita de Escúzar (Granada) y el travertino Olivillo de Alhama de Almería, con el fin de determinar su idoneidad para ser empleadas como piedras de sustitución en futuras intervenciones de restauración en el patrimonio arquitectónico de Andalucía Oriental.

\section{MATERIALES Y MÉTODOS}

\subsection{Materiales}

Las calcarenitas de Santa Pudia se han utilizado ampliamente en los edificios históricos más relevantes de la ciudad de Granada. La principal cualidad de esta roca en su uso como material de construcción es la facilidad para ser labrada; sin embargo su alta porosidad hace que también sea un material de escasa durabilidad $(7,14$, 15, 19-22). Las calcarenitas de Santa Pudia se localizan geológicamente en la cuenca intramontañosa de la depresión de Granada. Los materiales calcareníticos de edad Tortoniense Inferior son explotados fundamentalmente en el borde sur de la misma. En esta zona se encuentra el llamado Cortijo de Santa Pudia donde se localizan dos grandes canteras de calcarenita: La Escribana y Escúzar. En la cantera de Escúzar, situada al noroeste de la cantera de La Escribana, se extiende una serie de bancos calcareníticos claramente diferenciados de los anteriores por su textura, tamaño de bioclasto commonly used in monumental buildings in Granada. Piedra Franca, a calcarenite quarried at La Escribana (on the Santa Pudia Estate), was used to build Granada Cathedral, the Palace of Charles V, San Jerónimo Monastery, the Royal Hospital and the Royal Chancellery (3, 14-16). After La Escribana closed, quarrying operations were initiated at the Escúzar site, also known as Las Parideras and likewise located on the Santa Pudia Estate. The calcarenite extracted from the new site has recently been used to restore the mosque at Cordoba and The Five Wounds Palace at Seville (current headquarters of the Andalusian Parliament).

A second, scantly studied example is to be found in the travertine once quarried at Alfacar and used to build San Jerónimo Monastery, the Royal Hospital and three churches: San Justo, San Justo y Pastor and El Salvador. In some restoration interventions, Alfacar travertine has been replaced by Albox and Alhama, quarried at a number of sites in the province of Almería (Eastern Andalusia).

The present study aimed to characterize the aforementioned new stone varieties, Escúzar calcarenite from Granada and Olivillo travertine from Almería, to determine their suitability as replacement stone in future restoration work on monuments in Eastern Andalusia.

\section{MATERIALS AND METHODS}

\subsection{Materials}

Santa Pudia calcarenite was widely used to build the most significant historic buildings in the city of Granada. The characteristic that makes this rock particularly apt for construction is its ready workability. Nonetheless, its high porosity limits its durability considerably (7, 14, 15, 19-22). Geologically speaking, Santa Pudia calcarenite is located in the inter-mountain basin of the Granada depression. Lower Torteniense calcarenite materials are quarried primarily on the southern rim of that basin. This is the site of the so-called Santa Pudia Estate, home to two large calcarenite quarries, La Escribana and Escúzar. The Escúzar quarry, located NW of La Escribana, comprises a series of calcarenite banks with characteristic texture, bioclast size and macroscopic heterogeneity. La Escribana calcarenite, by contrast, has a more homogeneous pore distribution and bioclast size than the calcarenite that outcrops at Escúzar, which 
y elevada heterogeneidad macroscópica. La calcarenita de La Escribana tiene una distribución de poros y tamaños de bioclastos mucho más homogénea que la calcarenita que aflora en la cantera de Escúzar, donde se pueden distinguir tamaños de poros y xenoclastos de tamaños centimétricos y variaciones de porosidad macroscópica en niveles de aproximadamente $10 \mathrm{~cm}$ de potencia (Figuras $1 a$ y $1 b)$. En este trabajo se ha estudiado la calcarenita de Escúzar, suministrada por la fábrica Los Linos (23) ubicada en la localidad de Padul (suroeste de Granada).

El travertino Olivillo (Figura 1c) que se extrae en Alhama de Almería se emplea con frecuencia en la arquitectura moderna y es susceptible de ser utilizado en obras de restauración de edificios históricos (24). Desde el punto de vista constructivo, los travertinos poseen una buena resistencia mecánica y una alta resistencia a la abrasión. Las particularidades de su sistema poroso hacen, además, que se comporten favorablemente frente a la acción del agua impidiendo su ascenso capilar. En Andalucía Oriental se ha utilizado desde la antigüedad el travertino de Alfacar (Figura 1d), que se explotaba en el término municipal del mismo nombre al noreste de la ciudad de Granada $(15,18)$. Los travertinos de Alfacar se depositaron durante el Cuaternario sobre materiales de la cuenca intramontañosa en el borde noreste de la depresión de Granada. El cierre de las canteras de Alfacar ha propiciado el auge de la explotación de otros travertinos como los exhibits centimetre-scale pores and xenoclasts and variations in macroscopic porosity from one $10-\mathrm{cm}$ (approximately) layer to another (Figures $1 a$ and $1 b$ ). This study focused on Escúzar calcarenite, supplied by the Los Linos factory (23) located at Padul in SW Granada.

Olivillo travertine (Figure 1c), quarried at Alhama in the province of Almería, is commonly used in modern architecture and a candidate for use in the restoration of historic buildings (24). From a construction standpoint, travertine stone is a high-strength, abrasion-resistant material. Moreover, thanks to its pore system, it responds well to water, preventing capillary rise. Alfacar travertine (Figure 1d) has been used in Eastern Andalusia since antiquity. This stone is quarried in the municipal district of that name NE of the city of Granada $(15,18)$. It was deposited over materials in the intermountain basin on the NE rim of the Granada depression during the Quaternary Period. The closure of the Alfacar quarries led to more intensive exploitation of other travertine stones such as Albox and Alhama in Almería, as well as a rise in Roman travertine imports. $A$ substantial number of fairly extensive $\left(>5 \mathrm{~km}^{2}\right)$
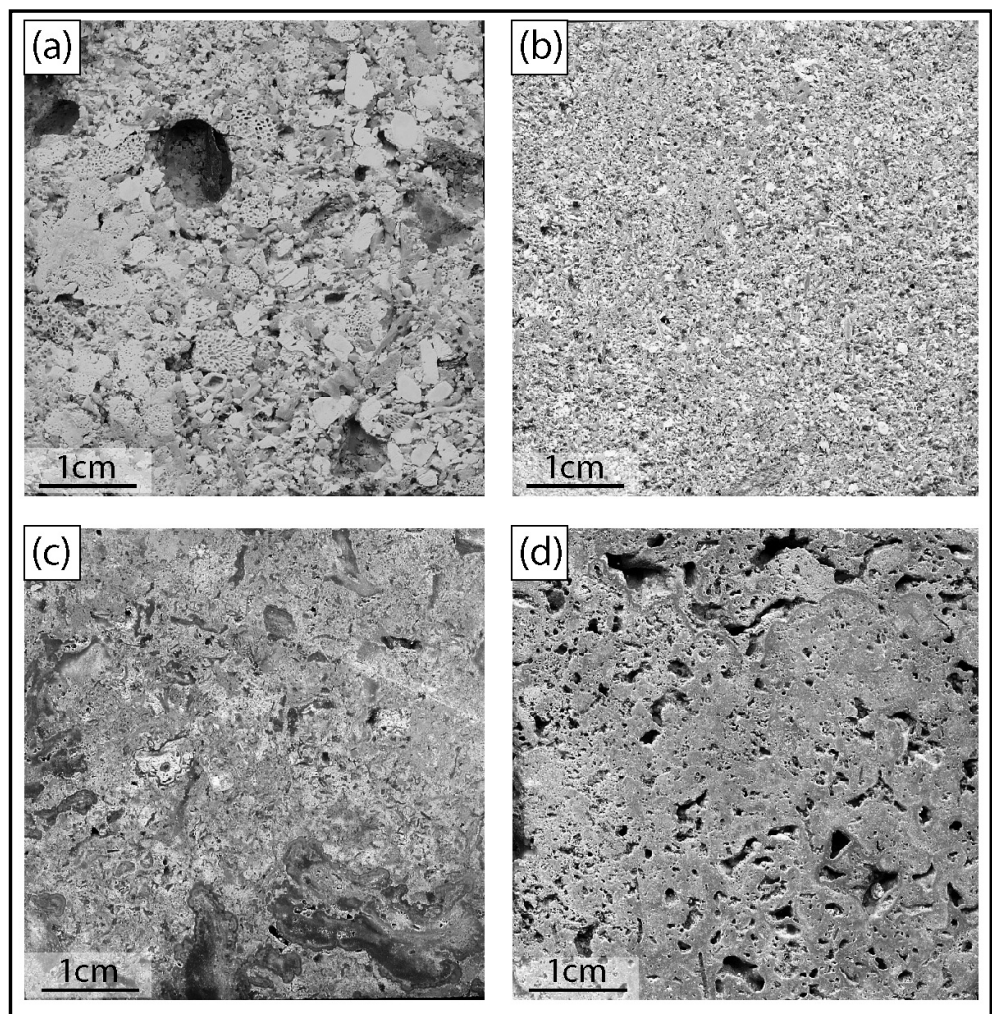

Figura 1. Aspecto macroscópico de (a) la calcarenita de Escúzar, (b) la calcarenita de La Escribana, (c) el travertino Olivillo y (d) el travertino de Alfacar.

Figure 1. Macroscopic view of (a) Escúzar calcarenite; (b) La Escribana calcarenite; (c) Olivillo travertine; and (d) Alfacar travertine. 
travertinos de Albox y de Alhama de Almería, y la importación del travertino romano. Cerca de las localidades de Alhama de Almería y Alicún afloran un gran número de formaciones travertínicas relativamente extensas ( $>5$ $\mathrm{km}^{2}$ ) de edad Cuaternario que aparecen sobre el Pleistoceno, Plioceno y Mioceno (24). Se caracterizan por su escasa porosidad a nivel macroscópico, débil bandeado composicional y ser estéticamente más llamativas que las del travertino de Alfacar (Figuras 1c y 1d). Estas formaciones travertínicas fueron depositadas en surgencias y en ambientes fluvio-lacustres, y posteriormente fueron afectadas por procesos de brechificación y alteración superficial más reciente (24-26). Los travertinos son explotados en varias canteras de las que se extrae la variedad Olivillo entre otras. En este trabajo se ha estudiado el travertino Olivillo, adquirido en la fábrica Mármoles Nevado (27) situada en la localidad de Atarfe (noroeste de Granada).

\subsection{Métodos}

La composición mineralógica de estos materiales pétreos se estableció mediante difracción de rayos X (DRX). Fragmentos de las muestras de cantera fueron molidas en un mortero de ágata, y el polvo resultante, con un tamaño inferior a $50 \mu \mathrm{m}$, se analizó mediante un difractómetro modelo Philips PW-1710 equipado con rendija automática. Las condiciones de trabajo fueron: radiación CuK $\alpha$ $(\lambda: 1.5405 \AA), 40 \mathrm{kV}$ de voltaje y $40 \mathrm{~mA}$ de intensidad de corriente. El ángulo de barrido estuvo comprendido entre $3^{\circ}$ y $60^{\circ} 2 \theta$, siendo la velocidad del goniómetro $0,01^{\circ}$ $2 \theta / \mathrm{s}$. El análisis semicuantitativo de las distintas fases minerales se hizo con el programa Xpowder (28).

Para analizar los elementos mayoritarios y traza de las rocas estudiadas se utilizó un espectrómetro de fluorescencia de rayos $\mathrm{X}$ por dispersión de longitud de onda, modelo S4 Pioneer-Bruker, con tubo de RH (60 kV, 150 $\mathrm{mA}$ ), cristales LIF200/PET/OVO-55 y detectores proporcionales de gas y de centelleo. Los espectros semicuantitativos se obtuvieron mediante el software Spectraplus $₫$. Las muestras en polvo $(\sim 5 \mathrm{~g})$ fueron homogeneizadas utilizando el dispositivo 5100 Spex Mixer/Mill. Posteriormente las muestras fueron depositadas uniformemente en un substrato de celulosa sobre un contenedor de aluminio de $40 \mathrm{~mm}$ de diámetro. La muestra en polvo fue compactada a $10 \mathrm{~T}$ (Mignon-S de Nannetti Instrument) para obtener pastillas comprimidas de $40 \mathrm{~mm}$ de diámetro.

El estudio petrográfico y mineralógico se realizó sobre láminas delgadas mediante microscopía óptica de luz transmitida, empleando un equipo Olympus BX-60, dotado de cámara fotográfica digital (Olympus DP10). Para distinguir la calcita de la dolomita las muestras se tiñeron con alizarina, que colorea selectivamente de rojo la calcita. travertine Quaternary formations, appearing over Pleistocene, Pliocene and Miocene materials, outcrop near the town of Alhama in Almería, as well as at Alicún. Characterized by scant macroscopic porosity and weak compositional banding, they have greater aesthetic appeal than Alfacar travertine (Figures 1c and 1d). These travertine formations were deposited during upwelling in fluvial-lacustrine environments and subsequently underwent brecciation and, more recently, surface alteration (24-26). Travertine, including the Olivillo variety, is extracted in several quarries. The object of the present study was Olivillo travertine, purchased at the Mármoles Nevado factory (27) at Atarfe in NW Granada.

\subsection{Methods}

The mineralogical composition of these stone materials was determined with X-ray diffraction (XRD). Quarry sample fragments were ground in an agate mortar and the resulting powder, with a particle size of under $50 \mu \mathrm{m}$, was analysed with a Philips PW-1710 diffractometer fitted with an automatic slit. The working conditions were: CuKa radiation ( $\lambda$ : $1.5405 \AA$ ), $40 \mathrm{kV}$ and $40 \mathrm{~mA}$. The $2 \theta$ scan angle ranged from $3^{\circ}$ to $60^{\circ}$, while the goniometer speed was $0.01^{\circ} 2 \theta / \mathrm{s}$. Semi-quantitative analysis of the mineral phases was performed with Xpowder software (28).

The major and the trace minor elements in the rocks studied were analysed with an 54 Pioneer-Bruker wavelength dispersive $X$-ray fluorescence spectrometer fitted with a (60 kV, $150 \mathrm{~mA}, \mathrm{Rh}$ anode) tube, LIF200/PET/OVO-55 crystals, proportional gas detectors and scintillation. Semi-quantitative spectra were obtained with Spectraplus $\mathbb{R}$ software. The powder samples ( $\sim \mathrm{g}$ ) were homogenized with a 5100 Spex Mixer/Mill and then evenly spread over a cellulose substrate on a 40- $\mathrm{mm}$ diameter aluminium container. The powder sample was compacted under a 10-t load with a Nannetti Instrument Mignon-S press to obtain 40-mm diameter wafers.

The petrographic and mineralogical study was conducted on thin sections under an Olympus BX-60 transmitted light optical microscope fitted with an Olympus DP10 digital camera. To distinguish calcite from dolomite, the samples were dyed with alizarin red, which dyes calcite selectively. 
El estudio de la microtextura y la composición de las muestras se realizó mediante un microscopio electrónico de presión variable (VPSEM) modelo LEO 1430-VP equipado con un filamento de wolframio y un sistema de microanálisis por dispersión de energía de RX (EDS) modelo Inca 350 de Oxford Instrument. Los resultados se procesaron con el software INCA $尺$. Las muestras fueron metalizadas con mezcla de oro y platino, y el estudio se hizo en alto vacío y a $15 \mathrm{kV}$. Los espectros fueron adquiridos en un rango desde 5 hasta $20 \mathrm{kV}$.

Para caracterizar el sistema poroso de las muestras rocosas se utilizó la porosimetría de inyección de mercurio (PIM) y la adsorción de argón. Para los análisis de porosimetría de mercurio se cortaron muestras de $2 \mathrm{~cm}^{3}$ de volumen, se secaron en horno a $60^{\circ} \mathrm{C}$ durante $24 \mathrm{~h}$ y se analizaron con un equipo Micromeritics Autopore III modelo 9410. Se obtuvieron isotermas de adsorción y desorción de argón a -196 C mediante un equipo Micromeritics TriStar 3000. En materiales pétreos es posible utilizar varios fluidos como adsorbatos, siendo el más común el nitrógeno. No obstante, cuando el área superficial de un material es menor de $5 \mathrm{~m}^{2} / \mathrm{g}$, el nitrógeno da valores superiores a los reales, por ello resulta más adecuado el uso de argón (29). Las muestras fueron calentadas antes de la medida a $250^{\circ} \mathrm{C}$ durante $7 \mathrm{~h}$ y desgasificadas a $10^{-3}$ Torr en un equipo Micromeritics Flowprep. El área superficial de cada muestra fue determinada mediante la linealización $\operatorname{BET}(30,31)$, mientras que la distribución de tamaño de poros, el volumen de poros y el tamaño medio de poro se calcularon usando el método $\mathrm{BJH}$ (32). Para caracterizar la rugosidad de la superficie del sistema poroso se calculó la dimensión fractal superficial, $D_{S}$. Las isotermas de adsorción de gas se estudiaron aplicando la ecuación modificada de Frenkel-Halsey-Hill (FHH) que permite determinar la dimensión fractal superficial a través de la pendiente $(A)$ de la gráfica $\operatorname{Ln}(\mathrm{V})$ vs $\operatorname{Ln}\left[\operatorname{Ln}\left(\mathrm{P} / \mathrm{P}_{0}\right)\right]$, donde $\mathrm{V}$ es el volumen de gas adsorbido, y $\mathrm{P}$ y $\mathrm{P}_{0}$ la presión del gas medida y la presión de condensación respectivamente. Cuando los efectos de la tensión superficial (o condensación capilar) son importantes, la relación entre $A$ y $D_{S}$ es $A=D_{S}-3$. Los efectos de condensación capilar son significativos cuando $\delta<0(\delta=3(1+A)-2)$. Para los casos estudiados el valor de $\delta$ fue siempre superior a la unidad, pudiéndose utilizar la expresión $A=D_{S}-3$. Para que la determinación de $D_{S}$ sea comparable entre distintas muestras es necesario utilizar una adsorción cercana a la monocapa (33). Por tanto, para calcular la pendiente (A) en el gráfico $\operatorname{Ln}(V)$ vs $\operatorname{Ln}\left[\operatorname{Ln}\left(\mathrm{P} / \mathrm{P}_{0}\right)\right.$ se utilizó exclusivamente un rango de presión que comprendiese un número de capas adsorbidas cercana a la unidad.

Para caracterizar el sistema poroso y conocer la dinámica de los fluidos en el interior de los distintos tipos pétreos se aplicaron los siguientes ensayos hídricos: absorción
Sample microtexture and composition were studied under a LEO 1430-VP variable pressure scanning electron microscope (VPSEM) fitted with a wolfram filament and an Oxford Instruments Inca 350 energydispersive $X$-ray (EDS) microanalysis system. The results were processed with INCA\& software. The gold- and platinum-coated samples were studied at $15 \mathrm{kV}$ in a high vacuum. The spectra were acquired in a range of 5 to 20 $k V$.

The pore system in the rock samples was characterized with mercury intrusion porosimetry (MIP) and argon adsorption. Two- $\mathrm{cm}^{3}$ samples were prepared for the mercury porosimetry analyses, kiln-dried at $60^{\circ} \mathrm{C}$ for 24 hours and subsequently analyzed with a Micromeritics Autopore III 9410 porosimeter. Argon adsorption and desorption isotherms were obtained at $-196{ }^{\circ} \mathrm{C}$ with a Micromeritics TriStar 3000 analyzer. The most common of the several fluids that can be used as adsorbates when studying stone materials is nitrogen. Nonetheless, for surface areas of under $5 \mathrm{~m}^{2} / \mathrm{g}$, the values delivered by nitrogen are higher than the actual quantities. Consequently, argon is more suitable in these cases (29). The samples were heated at $250^{\circ} \mathrm{C}$ for 7 hours and degassed at $10^{-3}$ Torr in a Micromeritics Flow Prep station before the measurements were taken. The surface area of each sample was determined by BET linearization $(30,31)$ while the pore size distribution, pore volume and mean pore size were found with the $B J H$ method (32). The surface fractal dimension, $D_{S}$, was used to characterize pore system surface roughness. The gas adsorption isotherms were studied applying the modified Frenkel-Halsey-Hill (FHH) equation, which determines the surface fractal dimension from the slope (A) of the $L n(V)$ vs the $L n\left[L n\left(P / P_{0}\right)\right]$ graph, where $V$ is the volume of the adsorbed gas and $P$ and $P_{0}$ are the gas pressure measured and the condensation pressure, respectively. When the surface tension (or capillary condensation) has significant effects, the ratio between $A$ and $D_{S}$ is $A=D_{S}-3$. The effects of capillary condensation are significant when $\delta<0(\delta=3(1+A)$ - 2). Given that in the cases studied the value of $\delta$ was consistently greater than one, the expression $A=D_{S}-3$ could be used. Single layer, or close to single layer, adsorption is required for the value of $D_{S}$ found to be comparable among different samples (33). Consequently, the range of pressures used to calculate slope $(A)$ in the $L n(V)$ vs $L n\left[L n\left(P / P_{0}\right)\right]$ graph was limited to values that ensured that the number of layers adsorbed was close to one.

The following hydric trials were conducted to characterize the pore system and determine the fluid dynamics inside the stones studied: free water 
y desorción libre de agua, saturación de agua bajo vacío, pesada hidrostática, ascenso y succión capilar. Siguiendo las normas UNE-EN 1925 (34), UNE-EN 13755 (35) y RILEM (36) se cortaron cubos de $5 \times 5 \times 5 \mathrm{~cm}$ a partir de las losas de cantera para los ensayos de absorción y desorción libre de agua, mientras que para los ensayos de ascenso y succión capilar se utilizaron probetas en forma de paralepípedo de $2 \times 2 \times 10 \mathrm{~cm}$. Antes de los ensayos se secaron las muestras en una estufa a $60^{\circ} \mathrm{C}$ durante $24 \mathrm{~h}$ para eliminar la humedad que pudieran contener.

Los análisis de pulsos ultrasónicos se realizaron usando un equipo Panametrics HV Pulser/Receiver 5058 PR acoplado a un osciloscopio Tektronix TDS 3012B. Se prepararon cubos de $5 \mathrm{~cm}$ de lado y se midieron las ondas $P$ y las ondas $\mathrm{S}$ mediante transductores con frecuencias de 0,5 $\mathrm{MHz}$ (ondas S) y $1 \mathrm{MHz}$ (ondas P). La velocidad de los pulsos ultrasónicos se determinó bajo las siguientes condiciones termohigrométricas: $\mathrm{T}=25^{\circ} \mathrm{C}$ y H.R. $=50 \%$. A partir del análisis digital de las señales transmitidas se calcularon los siguientes parámetros: velocidad de la onda compresiva $\left(V_{P}\right)$ y de cizalla $\left(V_{S}\right)$, coeficiente dinámico de Poisson $\left(v_{\mathrm{d}}\right)$, constante de elasticidad dinámica o módulo de Young $\left(E_{\mathrm{d}}\right)$, y los índices de anisotropía total $(\Delta \mathrm{M})$ y relativa $(\Delta \mathrm{m})$ de las ondas $\mathrm{P}$ y de las ondas $\mathrm{S}$, calculados según los índices propuestos por Guydader y Denis (37).

Las características cromáticas de las distintas variedades pétreas se estudiaron mediante un colorímetro Minolta CR 210 con $0^{\circ}$ de ángulo de visión y diámetro $50 \mathrm{~mm}$. Una lámpara de arco de Xenón, dentro de un compartimento mezclador, proporciona la difusión de la luz reflejada incluso alumbrando sobre un área de $50 \mathrm{~mm}$. Las medidas se llevaron a cabo utilizando un iluminante CIE D65, con una temperatura de color de $6774 \mathrm{~K}$ que simula la luz del día. Los datos obtenidos se expresaron mediante un código alfanumérico de los sistemas de color CIE L*a*b* y CIE $\mathrm{L}^{*} \mathrm{C}^{*} \mathrm{H}^{*}$ (38). Para cada loseta de $10 \times 10 \times 2 \mathrm{~cm}$ se determinó el valor de las coordenadas promedio L*a*b*, donde $L^{*}$ representa la luminosidad del color que varía desde el negro con un valor 0 hasta el blanco con un valor 100; $a^{*}$ que varía entre $+a^{*}$ (rojo) y -a* (verde), y b* que varía entre $+b^{*}$ (amarillo) y $-b^{*}(a z u l)$. El sistema CIELCH $\left(L^{*} C^{*} H^{*}\right)$ utiliza el mismo diagrama que el anterior pero usa coordenadas cilíndricas en vez de cartesianas, donde $L^{*}$ es la variable luminosidad, $C^{*}$ la saturación del color $\mathrm{y} \mathrm{H}^{*}$ el ángulo de matiz o tono.

\section{RESULTADOS Y DISCUSIÓN}

\subsection{Composición mineralógica y química}

La Tabla 1 muestra el análisis químico obtenido mediante FRX de elementos mayoritarios y determinados elementos minoritarios (como $\mathrm{Cu}, \mathrm{Zn}$, $\mathrm{Sr}$ y $\mathrm{Zr}$ ) para la calcarenita de absorption and desorption, vacuum water saturation, hydrostatic weight, and capillary rise and suction. Pursuant to Spanish and European standards UNE-EN 1925 (34) and UNE-EN 13755 (35) and RILEM (36), $5 x$ $5 \times 5 \mathrm{~cm}$ cubes were cut from quarry slabs to determine free water sorption, while $2 \times 2 \times 10 \mathrm{~cm}$ prismatic specimens were used for the capillary rise and suction trials. Before conducting the trials, the samples were kiln-dried at $60^{\circ} \mathrm{C}$ for 24 hours to remove any moisture they might contain.

The ultrasound velocity analyses were conducted on a Panametrics 5058 PR HV Pulser/Receiver operating in conjunction with a Tektronix TDS 3012B oscilloscope. Cubes measuring $5 \mathrm{~cm}$ on each side were prepared and the $P$ and $S$ waves measured with $0.5 \mathrm{HMz}$ ( $S$ waves) and $1 \mathrm{MHz}$ ( $P$ waves) transducers. The ultrasound velocity was determined at a temperature of $25^{\circ} \mathrm{C}$ and relative humidity of $50 \%$. The parameters calculated from a digital analysis of the signals transmitted were: compression $\left(V_{P}\right)$ and shear $\left(V_{S}\right)$ wave velocity, Poisson's ratio $\left(v_{d}\right)$, Young's modulus $\left(E_{d}\right)$ and the total $(\Delta M)$ and relative $(\Delta m) P$ and $S$ wave anisotropy indices, calculated from the indices proposed by Guydader and Denis (37).

The chromatic characteristics of the stone varieties were studied on a Minolta CR 210 colorimeter with a $0^{\circ}$ view angle and a 50-mm diameter. A xenon arc lamp inside a mixer compartment diffused the reflected light even when beamed on a 50- $\mathrm{mm}$ area. The measurements were taken with an IEC D65 illuminant having a daylightsimulating colour temperature of $6774 \mathrm{~K}$. The data obtained were expressed in an IEC $L^{*} a^{*} b^{*}$ and IEC $H^{*} S^{*} L^{*}(38)$ colour system alphanumeric codes. The mean values of the $L^{*} a * b *$ coordinates were determined for each $10 \times 10 \times 2 \mathrm{~cm}$ specimen, where $L^{*}$ is colour lightness, which varies from black with a value of 0 to white with a value of 100; $a^{*}$, which varies from $+a^{*}$ (red) to $-a^{*}$ (green) and $b^{*}$, ranging from $+b^{*}$ (yellow) to $-b^{*}$ (blue). The IECHSL $\left(H^{*} S^{*} L^{*}\right)$ system uses the same diagram as above but with cylindrical instead of Cartesian coordinates, where $H^{*}$ is hue, $\mathrm{S}^{*}$ is saturation and $L^{*}$ is lightness.

\section{RESULTS AND DISCUSSION}

\subsection{Mineralogical and chemical composition}

Table 1 gives the chemical analysis of all major and certain minor elements ( $\mathrm{Cu}, \mathrm{Zn}, \mathrm{Sr}$ and $\mathrm{Zr}$ ) obtained with XRF for Escúzar calcarenite and Olivillo 
Escúzary el travertino Olivillo. Asimismo aparecen los análisis de los litotipos extraídos de las canteras históricas, a saber, la calcarenita de La Escribana y el travertino de Alfacar usados tradicionalmente en monumentos antiguos de la ciudad de Granada.

Los datos de FRX (Tabla 1) revelan que en todas las litologías el calcio es el principal componente, indicando que están compuestas esencialmente por carbonato cálcico (calcita), composición confirmada mediante DRX. La calcarenita de Escúzar está ligeramente empobrecida en silicio, aluminio, hierro, magnesio, cinc y estroncio con respecto a la de La Escribana, y enriquecida en cobre y ligeramente en calcio.

El travertino Olivillo presenta valores más elevados de $\mathrm{CaO}$ y más bajos de $\mathrm{SiO}_{2}, \mathrm{Al}_{2} \mathrm{O}_{3}, \mathrm{Fe}_{2} \mathrm{O}_{3}, \mathrm{MgO}$, y $\mathrm{K}_{2} \mathrm{O}$ que el travertino de Alfacar (Tabla 1), así como concentraciones más elevadas de cobre, cinc, estroncio y circonio. La alta concentración en cinc y estroncio puede atribuirse a pequeñas cantidades de minerales metálicos detríticos (posiblemente esfalerita y celestina) atrapados durante la génesis en las formaciones travertínicas de Alhama de Almería (24).

Los resultados de DRX revelan que en todas las rocas la calcita es la principal fase mineral. Por lo que respecta a las calcarenitas, la roca de Escúzar presenta una composición mineralógica similar al subtipo E-1 de la calcarenita travertine. It also shows the analysis for the stones extracted from the historic quarries, namely the La Escribana calcarenite and Alfacar travertine traditionally used on monuments in the city of Granada.

According to the XRF data (Table 1), calcium was the main element in all the stones, an indication that they consist primarily of calcium carbonate (calcite). This was confirmed by the XRD findings. Escúzar calcarenite contained slightly less silicon, aluminium, iron, magnesium, zinc and strontium, and more copper and slightly more calcium than the La Escribana stone.

Olivillo travertine had higher values of $\mathrm{CaO}$ and lower values of $\mathrm{SiO}_{2}, \mathrm{Al}_{2} \mathrm{O}_{3}, \mathrm{Fe}_{2} \mathrm{O}_{3}, \mathrm{MgO}$ and $\mathrm{K}_{2} \mathrm{O}$ and higher concentrations of copper, zinc, strontium and zirconium than the Alfacar material (Table 1). The high zinc and strontium concentrations may be attributed to small amounts of detrital materials (possibly sphalerite and celestite) trapped in the travertine formations at Alhama (Spanish province of Almería) during genesis (24).

The XRD findings confirmed that calcite was the main mineral phase in all the rocks. The mineralogical composition proved to be similar, in the Escúzar rock and subtype E-1 La Escribana calcarenite $(14,15)$, which

Tabla 1 / Table 1

Análisis químico de elementos mayoritarios y minoritarios de calcarenitas y travertinos. Chemical analysis of major and minor elements in calcarenite and travertine stone.

\begin{tabular}{|c|c|c|c|c|c|c|}
\hline & \multicolumn{4}{|c|}{ Calcarenitas / Calcarenite } & \multicolumn{2}{|c|}{ Travertinos / Travertine } \\
\hline & Escúzar & \multicolumn{3}{|c|}{ Escribana* $^{*}$} & Olivillo & Alfacar* \\
\hline wt. \% & & E1 & E2 & E3 & & \\
\hline $\mathrm{SiO}_{2}$ & 0.31 & 2.83 & 1.79 & 2.38 & 0.96 & 14 \\
\hline $\mathrm{TiO}_{2}$ & $* *$ & 0.02 & 0.01 & 0.01 & 0.02 & - \\
\hline $\mathrm{Al}_{2} \mathrm{O}_{3}$ & 0.12 & 0.64 & 0.35 & 0.34 & 0.32 & 2.05 \\
\hline $\mathrm{Fe}_{2} \mathrm{O}_{3}$ & 0.12 & 0.14 & 0.27 & 0.49 & 0.12 & 0.86 \\
\hline $\mathrm{MnO}$ & 0.01 & 0.02 & 0.04 & 0.07 & $* *$ & - \\
\hline $\mathrm{MgO}$ & 0.28 & 0.3 & 0.46 & 0.44 & 0.72 & 2.15 \\
\hline $\mathrm{CaO}$ & 56.01 & 52.8 & 54.8 & 54.1 & 54.24 & 43.9 \\
\hline $\mathrm{K}_{2} \mathrm{O}$ & 0.02 & 0.09 & 0.06 & 0.07 & 0.06 & 0.38 \\
\hline $\mathrm{P}_{2} \mathrm{O}_{5}$ & 0.05 & 0.09 & 0.07 & 0.1 & 0.01 & 0.08 \\
\hline $\mathrm{SO}_{3}$ & 0.03 & - & - & - & 0.19 & - \\
\hline $\mathrm{Cl}$ & $* *$ & - & - & - & 0.01 & - \\
\hline \multicolumn{7}{|l|}{$\mathrm{ppm}$} \\
\hline $\mathrm{Cu}$ & 43 & 4.2 & 3.4 & 4.9 & 40 & 6.4 \\
\hline $\mathrm{Zn}$ & $* *$ & 15.8 & 60.6 & 24.3 & 1000 & 30.2 \\
\hline $\mathrm{Sr}$ & 185 & 318 & 457 & 358 & 1416 & 317 \\
\hline $\mathrm{Zr}$ & 7 & $<10$ & $<10$ & $<10$ & 55 & 27 \\
\hline
\end{tabular}

Límite de detección es 0.005 wt.\% para elementos mayoritarios, y para elementos minoritarios 3 ppm para Zr, 2 ppm para Sr y 1 ppm para Cu y Zn. / The detection threshold is $0.005 \%$ wt for major elements and 3 ppm for Zr, 2 ppm for Sr and 1 ppm for Cu and Zn.

* Valores tomados de (14) y (15). ** por debajo del límite de detección. - no medido. / * Extracted from (14) and (15). ** Below the detection threshold. - Not measured. 
histórica La Escribana $(14,15)$ compuesta principalmente por calcita (100-90\%) y en menor proporción cuarzo $(\sim 10 \%)$ y arcillas $(<1 \%)$, a diferencia de las variedades E-2 y E-3 cuyo contenido es superior en arcillas ( $>2,5 \%$ ) y feldespato ( $<5 \%$ en E-3). Los travertinos están compuestos en su mayoría por calcita, siendo su proporción menor en el travertino de Alfacar (84-100\%), donde también se ha detectado cuarzo (hasta $\sim 14 \%$ ), dolomita $(<5 \%)$ y feldespatos $(<1 \%)$.

\subsection{Características petrográficas}

La calcarenita de Escúzar está constituida por fragmentos de fósiles en una matriz clastosoportada, generados por la rotura de restos orgánicos mineralizados principalmente de bivalvos, equinodermos, foraminíferos, serpúlidos, briozoos y algas rojas. Los clastos de briozoos y algas rojas permanecen relativamente bien conservados como se muestra en las Figura $2 \mathrm{a}$ y $2 \mathrm{~b}$. Además, se han observado extraclastos procedentes de la erosión de materiales metamórficos de relieves cercanos de las Unidades Internas de las Cordilleras Béticas. La abundancia de estos extraclastos formados por fragmentos de rocas metamórficas ricas en micas y cuarzo, junto con la alta proporción de algas rojas y briozoos en relación con la de serpúlidos y equinodermos es una característica distintiva de esta cantera, que permite diferenciarla fácilmente de la calcarenita de La Escribana (14). Otra característica discriminatoria es la presencia de cavidades de hasta $2 \mathrm{~cm}$ de diámetro, como se aprecia en la Figura 1 .

La calcarenita histórica de La Escribana se caracteriza por presentar mayor cantidad de foraminíferos y serpúlidos, y menor tamaño de bioclasto, como se observa en las Figuras $2 \mathrm{c}$ y $2 \mathrm{~d}$. No obstante, en las dos calcarenitas estudiadas se pueden distinguir dos tipos de porosidad primaria: (a) una de pequeño tamaño parcialmente cementada, correspondiente a una porosidad intraclasto en foraminíferos y briozoos, y (b) una porosidad interclasto irregular, no cementada y de mayor tamaño. Además, se pone de manifiesto una baja interconexión entre la porosidad intra e interclasto.

El travertino Olivillo se caracteriza por un tamaño de poro relativamente pequeño y generalmente bien cementado. Las bandas claras y oscuras propias de la textura de este travertino se deben a cambios en la proporción relativa de cristales de calcita esparítica frente a la calcita microesparítica o micrítica. Las cavidades alargadas irregulares de gran tamaño ( 2 $\times 1 \mathrm{~mm})$, observadas en las Figuras $2 e$ y $2 f$, recuerdan a estructuras orgánicas de plantas que fueron parcial o totalmente rellenadas por calcita esparítica de tamaño 200 $\mu \mathrm{m}$. El material carbonático depositado originalmente entre los huecos dejados por la vegetación es de tamaño de grano mucho más fino $(\sim 20 \mu \mathrm{m})$. consists primarily of calcite (100-90\%), quartz ( 10\%) and clay (<1\%). This distinguishes it from the $E-2$ and E-3 varieties, which exhibit a higher clay (>2.5\%) and feldspar ( $<5 \%$ in E-3) content. Travertine was found to consist mostly of calcite, although in lower proportions in the Alfacar stone (84-100\%), which also contains quartz (up to $\sim 14 \%$ ), dolomite $(<5 \%$ ) and feldspar (<1\%).

\subsection{Petrographic characteristics}

Escúzar calcarenite was observed to comprise fossil fragments in a clast-supported matrix, generated by the fragmentation of mineralized organic remains, primarily of bivalves, echinoderms, foraminifers, serpulids, bryozoans and red algae. The bryozoan and red alga clasts were found to be fairly well preserved, as shown in Figures $2 a$ and $2 b$. Also observed were extraclasts, whose origin can be traced to the erosion of metamorphic materials from the nearby reliefs of Baetic Mountain Internal Units. The abundance of these extraclasts formed by fragments of mica- and quartz-rich metamorphic rock, together with a much higher proportion of red algae and bryozoans than serpulids and echinoderms, make the material quarried here readily distinguishable from La Escribana calcarenite (14). Another distinct characteristic of the Escúzar stone is the presence of vugs up to $2 \mathrm{~cm}$ in diameter, as depicted in Figure 1a.

Historic La Escribana calcarenite has more foraminifers and serpulids and fewer bioclasts than the Escúzar variety, as Figures $2 c$ and $2 d$ show. Two types of primary porosity can be distinguished in both calcarenite stones studied: (a) intraclast porosity in foraminifers and bryozoans, characterized by small, partially cemented pores; and (b) irregular interclast porosity with larger, uncemented pores. Moreover, scant interconnection was observed between intra- and interclast porosity.

The pore size in Olivillo travertine was fairly small and the pores generally well cemented. The light and dark bands characteristic of the texture of this travertine were found to be due to changes in the relative proportion of sparitic, microsparitic and micritic calcite. The large ( 2 $2 \times 1 \mathrm{~mm})$, irregular and elongated vugs observed in Figures $2 e$ and $2 f$ resemble the organic structures of plants that were partially or wholly filled with sparitic calcite grains around $200 \mu \mathrm{m}$ in size. The grains of carbonate material originally deposited between the voids left by the vegetation were much smaller $(-20 \mu \mathrm{m})$. 


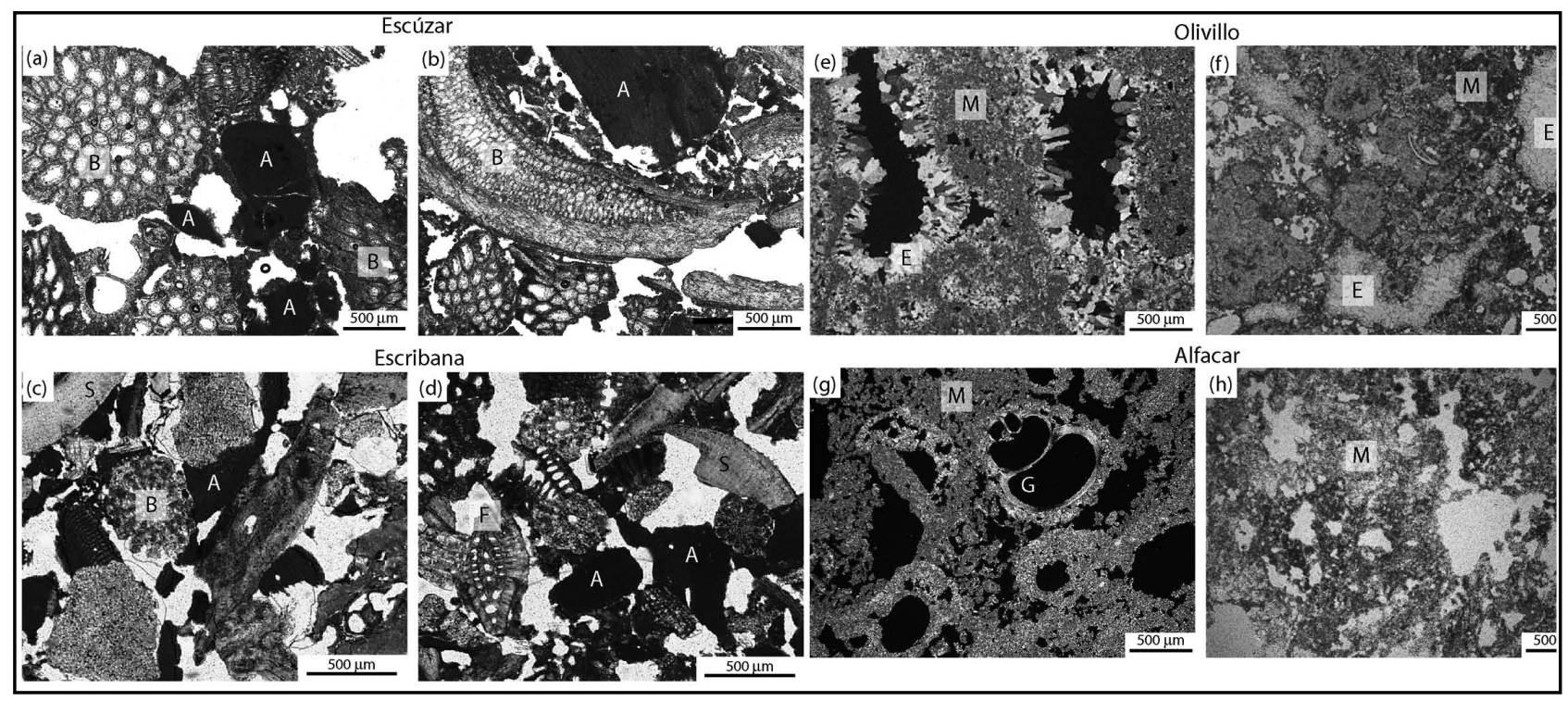

Figura 2. Microfotografías de láminas delgadas: (a) y (b) calcarenita de Escúzar (nícoles paralelos) mostrando bioclastos de grandes dimensiones (3-4 mm) de algas rojas (A) y briozoos (B). Fotografía (b) teñida con rojo de alizarina; (c) y (d) calcarenita de La Escribana (nícoles paralelos) mostrando bioclastos $(0.5-1 \mathrm{~mm})$ constituidos por algas rojas $(A)$, briozoos (B), serpúlidos (S) y foraminíferos (F); (e) y (f) travertino Olivillo mostrando en (e) matriz de calcita micrítica y cavidades alargadas ( $2 \times 1 \mathrm{~mm}$ ) tapizadas por cristales de calcita esparítica porosidad fenestral- (nícoles cruzados), y ( $f$ ) distribución irregular en la proporción de calcita micrítica (M) y calcita esparítica (E). (nícoles paralelos); $(\mathrm{g})$ y $(\mathrm{h}$ ) travertino de Alfacar mostrando en $(\mathrm{g})$ grandes poros debido a la existencia de abundantes restos fósiles de gasterópodos (G). La matriz es exclusivamente micrítica (M) (nícoles cruzados); (h) detalle de la porosidad irregular y heterogénea (nícoles paralelos). Figure 2. Microphotographs of thin sections. (a) and (b) Escúzar calcarenite (parallel Nicol prisms) showing large-scale (3-4 cm) red alga (A) and bryozoan (B) bioclasts; (b) dyed with alizarin red; (c) and (d) La Escribana calcarenite (parallel Nicol prisms) showing (0.5-1-mm) red alga

$(A)$, bryozoan $(B)$, serpulid $(S)$ and foraminifer $(F)$ bioclasts; (e) Olivillo travertine showing micritic calcite matrix and elongated ( $2 \times 1-\mathrm{mm})$ vugs lined with sparitic calcite crystals (fenestral porosity = intersecting Nicol prisms); (f) Olivillo showing irregular distribution of the proportions of micritic (M) and sparitic (E) calcite; ( $g$ ) Alfacar travertine showing an exclusively micritic matrix (M) (intersecting Nicol prisms) and large pores due to the presence of an abundance of gastropod fossils (G); and (h) Alfacar showing a detail of irregular and heterogeneous porosity (parallel Nicol prisms).

El estudio petrográfico del travertino histórico de Alfacar revela que es un travertino calcítico muy poroso. Se aprecia una textura de precipitación química sobre restos vegetales, donde se reconocen restos fósiles de gasterópodos (Figura $2 \mathrm{~g}$ ). La matriz es de calcita esencialmente micrítica. La porosidad es muy heterogénea, alcanzando los poros hasta tamaños centimétricos (coqueras). A diferencia del travertino Olivillo la porosidad fenestral del travertino de Alfacar se caracteriza por su escaso o nulo tapizado por calcita esparítica (Figuras $2 \mathrm{~g}$ y $2 \mathrm{~h}$ ).

\subsection{Características del sistema poroso}

\subsubsection{Porosimetría de inyección de mercurio}

La distribución y volumen de poro comprendidos entre tamaños de radio de acceso de poro de 0,003 $\mu \mathrm{m}$ y 100 $\mu \mathrm{m}$ se midieron mediante porosimetría de inyección de mercurio (PIM). Los resultados obtenidos se presentan en la Tabla 2 y la Figura 3, junto con los datos de las litologías de las canteras históricas, como la calcarenita de La Escribana y el travertino de Alfacar.

Los resultados del análisis PIM mostrados en la Tabla 2 revelan que la calcarenita de Escúzar es ligeramente más
Petrographic studies show that the historic stone from Alfacar is a very porous calcitic travertine. The texture is indicative of chemical precipitation on plant remains, in which gastropod fossils can be identified (Figure $2 g$ ). The matrix consists essentially of micritic calcite. Its porosity is very heterogeneous, with some centimetre-scale pores (vugs). Unlike Olivillo travertine, the Alfacar variety exhibits fenestral porosity characterized by a scant or nil sparitic calcite lining (Figures $2 g$ and $2 h$ ).

\subsection{Pore system characteristics}

\subsubsection{Mercury intrusion porosimetry}

The distribution and volume of pores with access radii of 0.003 to $100 \mu \mathrm{m}$ were measured with mercury intrusion porosimetry (MIP). The findings are set out in Table 2 and Figure 3, along with the lithological data for historic La Escribana calcarenite and Alfacar travertine.

The MIP findings given in Table 2 show that Escúzar calcarenite proved to be slightly more porous than the La 
Tabla 2 / Table 2

Características del sistema poroso mediante porosimetría de $\mathrm{Hg}$ (PIM) y adsorción de Ar. Pore system characteristics determined by mercury porosimetry (MIP) and Ar adsorption.

\begin{tabular}{|c|c|c|c|c|}
\hline \multirow[b]{2}{*}{$\begin{array}{l}\text { Porosimetría de } \mathrm{Hg} / \\
\text { Hg porosimetry }\end{array}$} & \multicolumn{2}{|c|}{ Calcarenitas / Calcarenite } & \multicolumn{2}{|c|}{ Travertinos / Travertine } \\
\hline & Escúzar & Escribana * & Olivillo & Alfacar * \\
\hline $\begin{array}{c}\text { Porosidad abierta (\%) / Effective } \\
\text { porosity (\%) }\end{array}$ & $29.30 \pm 7.60$ & $24.50 \pm 6.75$ & $8.16 \pm 1.21$ & 20.8 \\
\hline $\begin{array}{l}\text { Densidad real }\left(\mathrm{g} \mathrm{cm}^{-3}\right) / \text { Real density } \\
\qquad\left(\mathrm{g} \mathrm{cm}^{-3}\right)\end{array}$ & $2.52 \pm 0.25$ & $2.46 \pm 0.21$ & $2.65 \pm 0.04$ & 2.57 \\
\hline $\begin{array}{l}\text { Densidad aparente }\left(\mathrm{g} \mathrm{cm}^{-3}\right) / \text { Bulk } \\
\text { density }\left(\mathrm{g} / \mathrm{cm}^{-3}\right)\end{array}$ & $1.96 \pm 0.39$ & $1.96 \pm 0.25$ & $2.43 \pm 0.04$ & 2.04 \\
\hline \multicolumn{5}{|l|}{ Adsorción de Ar / Ar adsorption } \\
\hline $\begin{array}{c}\text { Área superficial }\left(\mathrm{m}^{2} / \mathrm{g}\right) / \text { Specific } \\
\text { surface area }\left(\mathrm{m}^{2} / \mathrm{g}\right)\end{array}$ & $0.7137 \pm 0.1077$ & $1.6506 \pm 0.0060$ & $0.5601 \pm 0.1042$ & $0.6246 \pm 0.0022$ \\
\hline $\begin{array}{l}\text { Volumen total de poros }\left(\mathrm{cm}^{3} / \mathrm{g}\right) / \\
\text { Total pore volume }\left(\mathrm{cm}^{3} / \mathrm{g}\right)\end{array}$ & $0.00049 \pm 0.00006$ & 0.00130 & $0.00037 \pm 0.00007$ & 0.00061 \\
\hline $\begin{array}{c}\text { Diámetro medio de poro }(\AA) \text { / Pore } \\
\text { diameter }(\AA)\end{array}$ & $19.72 \pm 1.54$ & 19.04 & $20.53 \pm 1.48$ & 19.01 \\
\hline $\begin{array}{l}\text { Volumen de monocapa }\left(\mathrm{cm}^{3} / \mathrm{g}\right) / \\
\text { Single layer volume }\left(\mathrm{cm}^{3} / \mathrm{g}\right)\end{array}$ & $0.1667 \pm 0.0326$ & $0.4165 \pm 0.0228$ & $0.1468 \pm 0.0270$ & 0.1637 \\
\hline $\begin{array}{l}\text { Dimensión fractal superficial }\left(D_{S}\right) / \\
\text { Fractal surface dimension }\left(D_{S}\right)\end{array}$ & 2.60 & 2.70 & 2.52 & 2.64 \\
\hline $\begin{array}{l}\text { Coeficiente linear de correlación }\left(r^{2}\right) / \\
\text { Linear correlation coefficient }\left(r^{2}\right)\end{array}$ & 0.9835 & 0.9912 & 0.9974 & 0.9923 \\
\hline
\end{tabular}

Valores presentados son la media y la desviación estándar de 3 medidas. / The values shown are the mean of 3 measurements and the respective standard deviation.

- Valores no disponibles, * Rocas históricas. Valores tomados de (14). / - Values not available. * Historic rock. Values extracted from (14).

porosa que la de La Escribana, con valores de 29,3 \pm $7,6 \%$ frente a $24,50 \pm 6,75 \%$ respectivamente; ambas rocas poseen la misma densidad aparente. Como se aprecia en la Figura $3 a$ y $3 b$ las calcarenitas estudiadas presentan una evidente distribución bimodal de poros. La calcarenita de Escúzar tiene un máximo absoluto a 0,3 $\mu \mathrm{m}$ y otro relativo más difuso entre 3 y $100 \mu \mathrm{m}$. Por el contrario, la proporción de poros comprendida entre 3 y $100 \mu \mathrm{m}$ es mayor en la calcarenita de La Escribana, aunque la presencia de poros de 0,3 $\mu \mathrm{m}$ también es significativa (39).

Existe un importante contraste de las características del sistema poroso accesible al $\mathrm{Hg}$ entre el travertino Olivillo y el de Alfacar (Tabla 2). El travertino Olivillo es mucho menos poroso que el de Alfacar con un valor de 8,16 \pm $1,21 \%$ frente a $20,8 \%$ respectivamente. El travertino Olivillo posee una densidad aparente muy superior, atribuida a la mayor densidad real de sus minerales constituyentes, y a la ya mencionada menor porosidad abierta. Las Figuras 3 c y $3 d$ revelan que la distribución de tamaños de poros en los travertinos estudiados contrasta con la de las calcarenitas. Los travertinos poseen una distribución unimodal. El travertino Olivillo tiene un máximo comprendido entre 0,02 y $0,07 \mu \mathrm{m}$, mientras que en el travertino Alfacar la mayoría de los poros accesibles a esta técnica se concentran entorno a $1 \mu \mathrm{m}$.
Escribana variety, with values of $29.3 \pm 7.6 \%$ and 24.50 $\pm 6.75 \%$, respectively. The two rocks exhibited the same bulk density. As Figures $3 a$ and $3 b$ show, the calcarenite stones studied had a clearly bimodal pore distribution. The curve for Escúzar calcarenite had an absolute peak at $0.3 \mu \mathrm{m}$ and a fairly diffuse second peak at 3 to 100 $\mu \mathrm{m}$. By contrast, the proportion of 3- to $100-\mu \mathrm{m}$ pores was larger in La Escribana calcarenite, although this stone also exhibited a significant presence of $0.3-\mu m$ pores (39).

The pore system accessible to mercury differed greatly between the Olivillo and Alfacar travertine stones (Table 2). Olivillo travertine proved to be much less porous than the Alfacar stone, with a value of $8.16 \pm 1.21 \%$ compared to $20.8 \%$. Olivillo travertine was characterized by a much higher bulk density, attributed to the higher actual density of its constituent minerals and its smaller effective porosity, mentioned above. Figures $3 c$ and $3 d$ show that the pore size distribution differed in the travertine and calcarenite rocks studied. In the travertine materials it was unimodal. The Olivillo travertine peaked at 0.02 to $0.07 \mu \mathrm{m}$, whereas in the Alfacar travertine most of the pores accessible to this technique measured around $1 \mu \mathrm{m}$. 


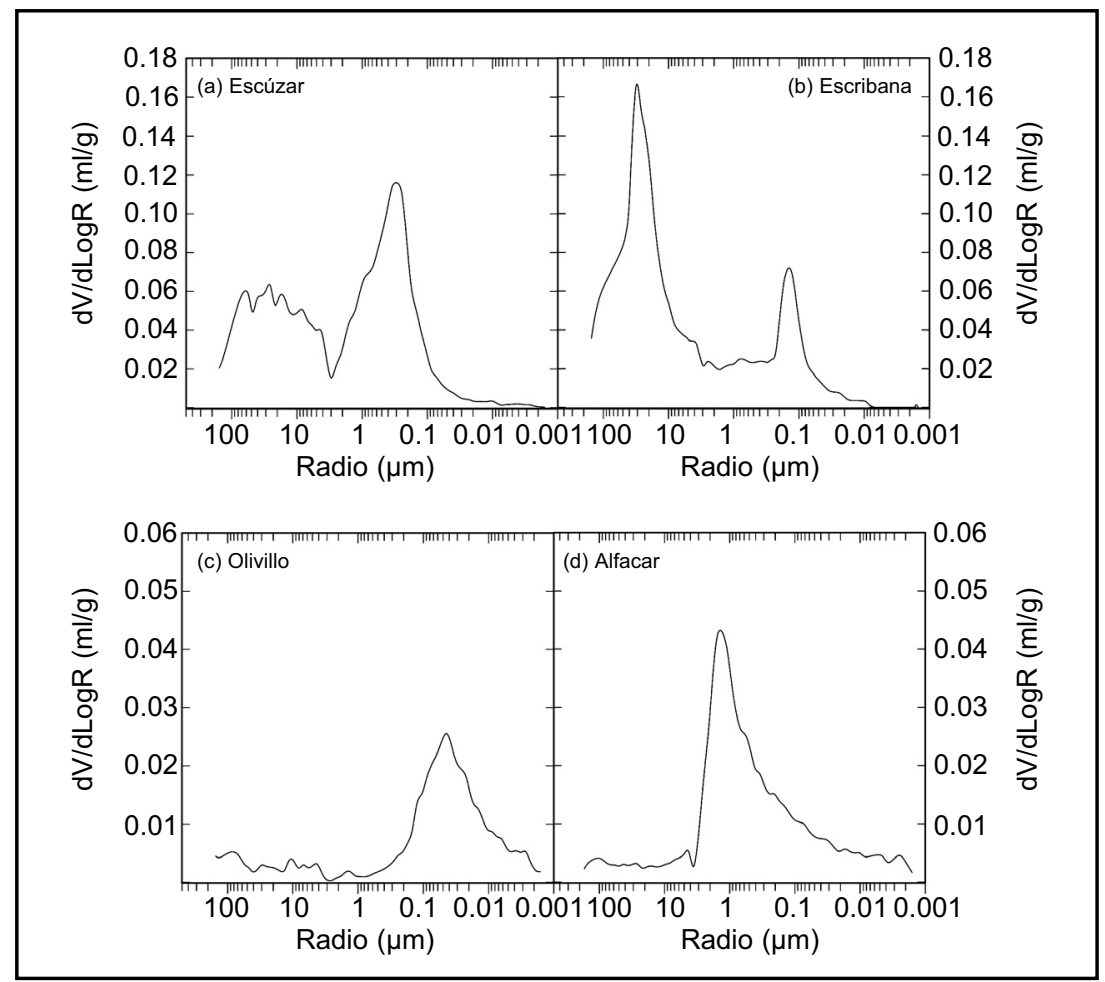

Figura 3. Distribución de tamaños de poros obtenidos mediante porosimetría de inyección de mercurio (PIM) para (a) calcarenita de Escúzar, (b) calcarenita de La Escribana, (c) travertino Olivillo y (d) travertino de Alfacar. (b) Tomado de (39).

Figure 3. Pore size distribution found with mercury intrusion porosimetry (MIP) for (a) Escúzar calcarenite; (b) La Escribana calcarenite; (c) Olivillo travertine; and (d) Alfacar travertine; (b) taken from (39).

\subsubsection{Adsorción de argón}

El sistema poroso comprendido entre tamaños de radio de acceso de poro de 0,001 $\mu \mathrm{m}$ y 0,006 $\mu \mathrm{m}(10-60 \AA)$, se caracterizó en detalle mediante adsorción de argón, mostrándose los resultados en la Tabla 2. La adsorción de Ar revela que la calcarenita de Escúzar posee menor área superficial $\left(0,7137 \pm 0,1077 \mathrm{~m}^{2} / \mathrm{g}\right)$ que la roca histórica $\left(1,6506 \pm 0,0060 \mathrm{~m}^{2} / \mathrm{g}\right)$, así como menor volumen total de poros accesibles a esta técnica (Tabla 2). Existen claras diferencias en la estructura del sistema poroso de ambas calcarenitas, que se refleja en su dimensión fractal superficial. Valores superiores de este índice en la calcarenita de La Escribana $(2,70)$ frente a la roca de Escúzar $(2,60)$ indican un sistema microporoso más complejo y susceptible al deterioro de aquella $(40,41)$.

Las diferencias entre el sistema microporoso de los dos travertinos estudiados es en cambio menor. Ambos poseen un área superficial y un volumen total de poros similar. Sin embargo, el travertino Alfacar presenta un sistema poroso más complejo que el travertino Olivillo. De los resultados presentados se deduce que las rocas susceptibles de ser empleadas como sustitutas de las históricas, tengan potencialmente menos predisposición al deterioro por ataque químico que las rocas históricas; es decir, a los procesos de disolución del cemento carbonático por acción salina o por soluciones acuosas ácidas $(40,41)$.

\subsubsection{Argon adsorption}

The pore system with access radii ranging from 0.001 to $0.006 \mu \mathrm{m}$ (10-60 $\AA$ ) was characterized in depth by argon adsorption. The findings in Table 2 show that Escúzar calcarenite had a smaller surface area $(0.7137 \pm 0.1077$ $\left.\mathrm{m}^{2} / \mathrm{g}\right)$ than the historic rock $\left(1.6506 \pm 0.0060 \mathrm{~m}^{2} / \mathrm{g}\right)$, as well as a smaller total volume of pores accessible to this technique (Table 2). Clear differences were found between the pore systems of the two calcarenite stones, as reflected in their surface fractal dimension. The higher values of this index in the La Escribana (2.70) than in the Escúzar stone (2.60) are indicative of a more complex micropore system, more liable to deterioration in the former $(40,41)$.

The differences in the mircropore systems in the two travertine rocks were found to be smaller. The two materials have similar surface area and total pore volume values. The Alfacar stone has a more complex pore system than the Olivillo variety, however. The inference of the above findings is that the rocks potentially able to replace the historic materials are less prone to chemically induced (i.e., dissolution of the carbonate cement by salts or aqueous acid solutions) deterioration than the historic stone $(40,41)$. 


\subsection{Parámetros hídricos}

Los parámetros hídricos como la absorción y desorción libre de agua, y ascenso y succión capilar, son determinantes para la idoneidad de un material constructivo a la hora de sustituir a otro como elemento arquitectónico $(6,13)$. La Tabla 3 y la Figura 4 muestran que el valor medio de absorción libre de agua en la calcarenita de Escúzar fue de $16,30 \pm 2,42 \%$ a las $168 \mathrm{~h}$ del inicio del ensayo, superior al valor medio de $12,75 \%$, obtenido en la calcarenita histórica de La Escribana (14). Las Figuras 4a y 4b revelan que ambas calcarenitas siguen un patrón similar, alcanzando respectivamente valores de $\sim 14 \%$ y $12 \%$ de absorción libre de agua a los pocos minutos ( $-4 \mathrm{~min})$ transcurridos desde el inicio del ensayo. Por su parte, el travertino Olivillo presenta una velocidad de absorción de agua lenta en el primer tramo de la curva, ralentizándose aún más a lo largo del ensayo, alcanzándose un valor máximo de tan sólo $2-2,5 \%$ en 47 h (Figura 4c). Estos valores son parecidos a los obtenidos por Karaca (43) en travertinos procedentes de Turquía. El comportamiento hídrico del travertino de Alfacar difiere notablemente, puesto que aproximadamente en la primera hora del ensayo se alcanzaron valores de absorción libre de agua superiores al $8 \%$ (Figura 4d).

Las curvas de desorción libre de agua para las calcarenitas (Figuras 4a y 4b) difieren de manera significativa. La calcarenita de Escúzar muestra un tramo inicial donde apenas se produce secado (Figura 4a). En cambio, la calcarenita de La Escribana presenta un único tramo con una velocidad de desorción mayor (Figura 4b). El secado de la calcarenita histórica La Escribana se produjo a las $49 \mathrm{~h}$ del inicio del ensayo, frente a las más de $121 \mathrm{~h}$ empleadas en el secado de la calcarenita de Escúzar.

\subsection{Hydric parameters}

Hydric parameters such as free water absorption and desorption and capillary rise and suction determine the suitability of a given construction material as a replacement of another in architectural structures (6, 13). Table 3 and Figure 4 show that, 168 hours into the trial, mean free water absorption in the Escúzar calcarenite was $16.30 \pm 2.42 \%$. This is higher than the $12.75 \%$ reported for the historic La Escribana stone (14). Figures $4 a$ and $4 b$ show that the two calcarenite rocks followed similar patterns, respectively reaching free water absorption values of $\sim 14$ and $12 \%$ shortly after ( $4 \mathrm{~min}$ ) the trial began. Olivillo travertine, in turn, exhibited slow water absorption in the first segment of the curve, which slowed further throughout the trial, with a value of only 2-2.5\% after 47 hours (Figure 4c). These values were similar to the findings reported by Karaca (43) for Turkish travertine. The hydraulic behaviour of the Alfacar travertine differed considerably, reaching free water absorption values of over $8 \%$ in the first hour of the trial (Figure 4d).

The free water desorption curves for the calcarenite stones (Figures $4 a$ and $4 b$ ) differed significantly. The curve for Escúzar calcarenite had an initial segment in which barely any drying was detected (Figure 4a). The La Escribana calcarenite curve, by contrast, had a single and higher desorption rate (Figure 4b). Historic La Escribana calcarenite dried after 49 hours, compared to the over 121 hours needed to dry the Escúzar stone.

Tabla 3 / Table 3

Valores obtenidos a través de los ensayos hídricos. Hydric trial findings.

\begin{tabular}{|c|c|c|c|c|}
\hline & \multicolumn{2}{|c|}{ Calcarenitas / Calcarenite } & \multicolumn{2}{|c|}{ Travertinos / Travertine } \\
\hline & Escúzar & Escribana* & Olivillo & Alfacar \\
\hline $\begin{array}{c}\text { Porosidad abierta (\%) / Effective } \\
\text { porosity (\%) }\end{array}$ & $31.86 \pm 3.09$ & 20.43 & $6.83 \pm 0.82$ & $23.7 \pm 3.00$ \\
\hline $\begin{array}{l}\text { Densidad real }\left(\mathrm{g} / \mathrm{cm}^{3}\right) / \text { Real density } \\
\left(\mathrm{kg} / \mathrm{cm}^{3}\right)\end{array}$ & $2.48 \pm 0.05$ & 2.46 & $2.60 \pm 0.01$ & $2.37 \pm 0.05$ \\
\hline $\begin{array}{c}\text { Densidad aparente }\left(\mathrm{g} / \mathrm{cm}^{3}\right) / \text { Bulk } \\
\text { density }\left(\mathrm{g} / \mathrm{cm}^{3}\right)\end{array}$ & $1.69 \pm 0.06$ & 1.96 & $2.43 \pm 0.02$ & $1.81 \pm 0.11$ \\
\hline $\begin{array}{c}\text { Absorción libre de agua (\%) / Free } \\
\text { water absorption (\%) }\end{array}$ & $16.30 \pm 2.42$ & 12.75 & $2.28 \pm 0.23$ & $10.46 \pm 1.62$ \\
\hline $\begin{array}{c}\text { Desorción libre de agua (\%) / Free } \\
\text { water desorption (\%) }\end{array}$ & $14.80 \pm 1.37$ & - & $2.53 \pm 0.26$ & $11.46 \pm 1.92$ \\
\hline Saturación (\%) / Saturation (\%) & $78.36 \pm 1.72$ & 73.98 & $82.31 \pm 2.17$ & $72.96 \pm 4.23$ \\
\hline $\begin{array}{c}\text { Velocidad de ascenso capilar }\left(\mathrm{cm} / \mathrm{h}^{1 / 2}\right) / \\
\text { Rate of capillary rise }\left(\mathrm{cm} / \mathrm{h}^{1 / 2}\right)\end{array}$ & $3.24 \pm 0.81$ & 2.96 & - & - \\
\hline $\begin{array}{c}\text { Succión capilar }\left(\mathrm{g} / \mathrm{cm}^{2 *} \mathrm{~h}^{1 / 2}\right) / \text { Capillary } \\
\text { suction }\left(\mathrm{g} / \mathrm{cm}^{2 *} h^{1 / 2}\right)\end{array}$ & $0.76 \pm 0.26$ & 0.68 & $0.03 \pm 0.01$ & 0.12 \\
\hline
\end{tabular}

Valores presentados son la media y la desviación estándar de 3 medidas. / The values shown are the mean of 3 measurements and the respective standard deviation. - Valores no disponibles. * Roca histórica. Valores tomados de (14) y (42). / - Values not available. * Historic rock. Values extracted from (14) and (42). 


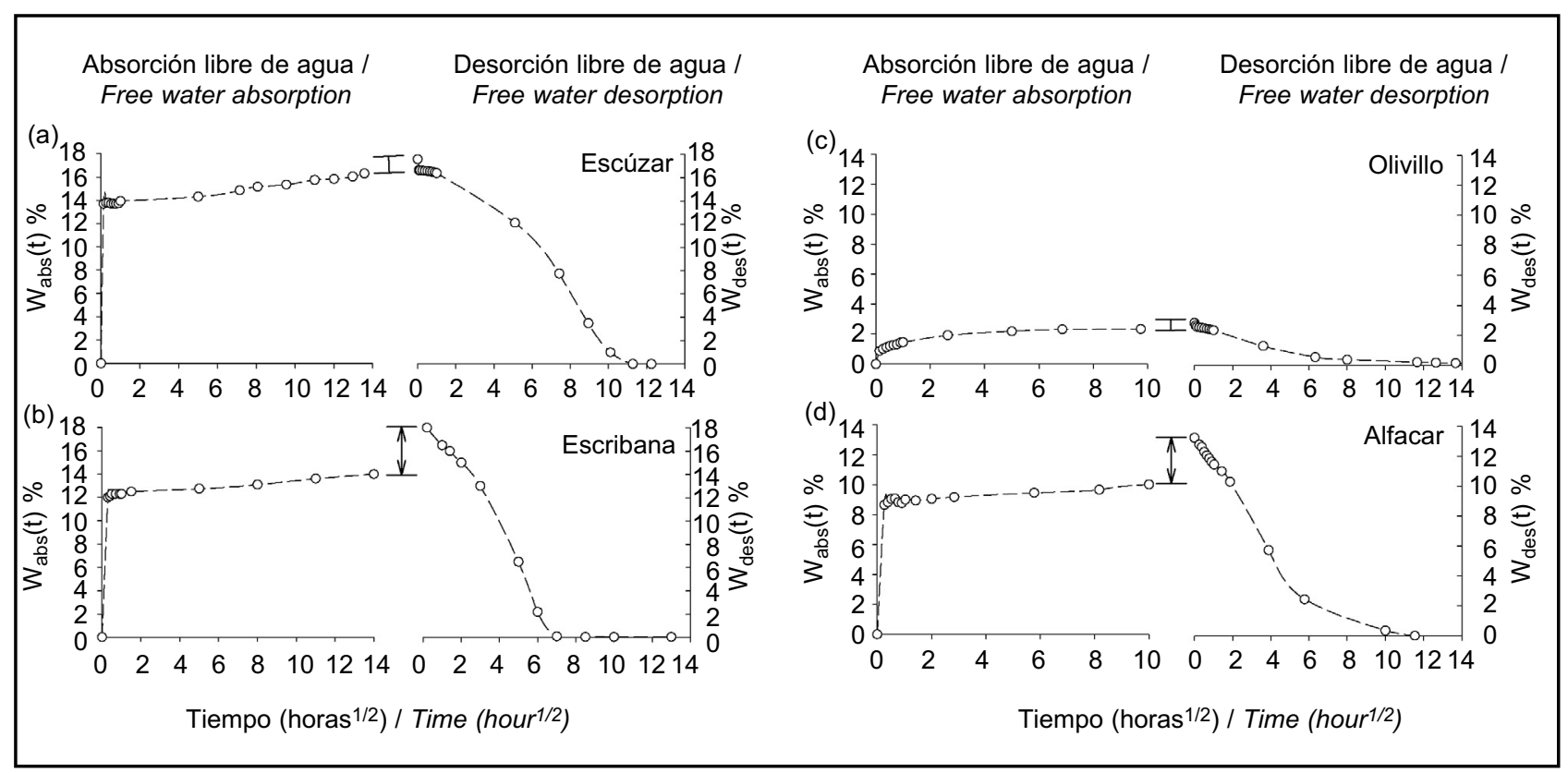

Figura 4. Parámetros hídricos. Curvas de absorción y desorción libre de agua para (a) calcarenita de Escúzar, (b) calcarenita de La Escribana, (c) travertino Olivillo y (d) travertino de Alfacar. (b) Tomado de (14).

Figure 4. Hydric parameters: free water absorption and desorption curves for (a) Escúzar calcarenite; (b) La Escribana calcarenite; (c) Olivillo travertine; and (d) Alfacar travertine; (b) taken from (14).

La curva de desorción libre de agua del travertino OliviIlo muestra un tramo aproximadamente constante, estando la roca aún saturada transcurridas $196 \mathrm{~h}$ desde el inicio del ensayo (Figura 4c). En cambio, el travertino Alfacar presenta dos tramos distinguibles, produciéndose el secado más rápido en las primeras $25 \mathrm{~h}$ y secándose totalmente la roca antes de las $144 \mathrm{~h}$ (Figura 4d). El comportamiento hídrico del travertino Olivillo se justificaría por la presencia de abundantes microporos aislados. Así, el agua que accedió a los microporos durante la absorción forzada al vacío quedó retenida en su interior impidiendo la desorción completa. Por el contrario, el mayor tamaño de poros en el travertino Alfacar favorece su secado total.

Como muestra la Tabla 3, la velocidad de ascenso capilar sólo pudo ser determinada para las calcarenitas. La roca de Escúzar presenta un valor de 3,24 $\pm 0,81$ $\mathrm{cm} / \mathrm{h}^{1 / 2}$, ligeramente superior al valor de $2,96 \mathrm{~cm} / \mathrm{h}^{1 / 2}$ obtenido en la calcarenita de La Escribana. Este hecho pone de manifiesto importantes diferencias en las propiedades físicas entre los dos materiales explotados en la misma unidad litológica. Por otra parte, el coeficiente de succión capilar (Tabla 3) pudo medirse en las cuatro variedades rocosas mediante la pendiente del primer tramo recto de la curva de succión en la primera hora del ensayo (Figura 5). La Tabla 3 revela que el coeficiente de succión capilar en la calcarenita de Escúzar $(0,76 \pm$ $0,26 \mathrm{~g} / \mathrm{cm}^{2} \cdot \mathrm{h}^{1 / 2}$ ) es, aunque superior, similar al de la calcarenita de La Escribana $\left(0,68 \mathrm{~g} / \mathrm{cm}^{2} \cdot \mathrm{h}^{1 / 2}\right)$.
The free water desorption curve for Olivillo travertine stabilized, and the rock was still moist 196 hours after the trial started (Figure 4c). The Alfacar curve, in contrast, has two distinct segments, with quicker drying taking place in the first 25 hours and total drying recorded after 144 hours (Figure 4d). The hydraulic behaviour of Olivillo travertine would be explained by the presence of many isolated micropores. The water reaching the micropores during forced vacuum absorption would be retained in these pores, preventing complete desorption. The larger pore size in the Alfacar travertine, by contrast, would favour total drying.

As Table 3 shows, capillary rise could only be determined for the calcarenite stones. The Escúzar variety had a value of $3.24 \pm 0.81 \mathrm{~cm} / \mathrm{h}^{1 / 2}$, which was slightly higher than the $2.96 \mathrm{~cm} / \mathrm{h}^{1 / 2}$ found for the La Escribana stone. This finding revealed substantial differences in the physical properties of the two materials extracted from the same lithological unit. The capillary suction coefficient (Table 3) could be measured in all four rock varieties from the slope of the first straight segment on the suction curve during the first hour of the trial (Figure 5). Table 3 shows that the capillary suction coefficient in Escúzar calcarenite $\left(0.76 \pm 0.26 \mathrm{~g} / \mathrm{cm}^{2} \cdot h^{1 / 2}\right)$ was, while higher, similar to the value for the La Escribana stone $\left(0.68 \mathrm{~g} / \mathrm{cm}^{2} \cdot \mathrm{h}^{1 / 2}\right)$. 


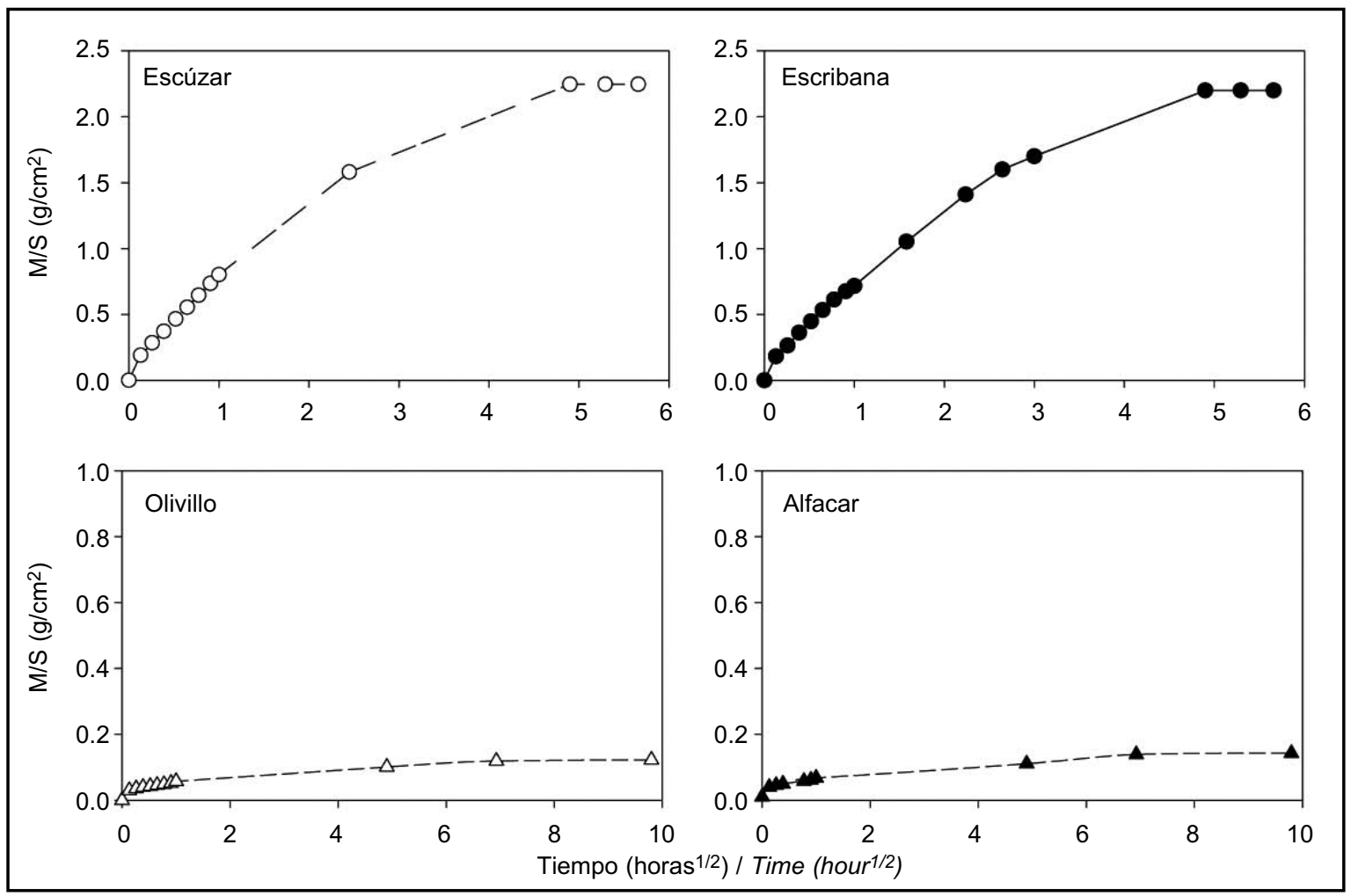

Figura 5. Curvas de succión capilar de agua para (a) calcarenita de Escúzar, (b) calcarenita de La Escribana, (c) travertino Olivillo y (d) travertino de Alfacar. (b) Tomado de (14).

Figure 5. Capillary water suction curves for (a) Escúzar calcarenite; (b) La Escribana calcarenite; (c) Olivillo travertine; and (d) Alfacar travertine; (b) taken from (14).

\subsection{Parámetros ultrasónicos}

Las propiedades mecánicas de diversas rocas han sido determinadas de manera extensiva mediante la medida de la velocidad de propagación de las ondas ultrasónicas, ya que pueden ser utilizadas para evaluar la resistencia de un material frente a esfuerzos $(6,8,37,44,45)$. Con el fin de determinar estas propiedades en las rocas estudiadas, en este trabajo se realizaron medidas de la velocidad de las ondas $\mathrm{P}$ y $\mathrm{S}$ según tres direcciones ortogonales, recogidas en la Tabla 4. En la calcarenita histórica de La Escribana no han podido medirse las ondas S, por no disponer de muestras con las dimensiones adecuadas para tal ensayo. Más aún, tampoco se han encontrado datos en la bibliografía.

En la calcarenita de Escúzar la velocidad de transmisión de las ondas $\mathrm{P}$ fue superior a la velocidad sónica medida en la roca histórica de La Escribana, siendo mayor la desviación estándar en la velocidad de las ondas $\mathrm{P}$ que en las ondas S (Tabla 4). Esta alta desviación debe atribuirse a su marcada heterogeneidad textural, observable a simple vista. Ambas calcarenitas presentan una anisotropía moderada-baja, siendo mayor la anisotropía total que la relativa en las dos rocas, en particular en la de Escúzar. Por su parte, la anisotropía total $(\Delta \mathrm{Mp})$ de la roca de Escúzar es superior a la de La Escribana, con valores de 9,2\%

\subsection{Ultrasound parameters}

The mechanical properties of a number of rocks have been determined by measuring the propagation velocity of ultrasound waves, a technique for evaluating force resistance in materials $(6,8,37,44,45)$. These properties were determined in the rocks studied by measuring the $P$ and $S$ wave velocity in the three spatial directions. The findings are given in Table 4 . The $S$ wave velocity could not be measured in historic La Escribana calcarenite, for want of samples of a size suitable for the trial. Nor were data on this material found in the literature.

The $P$ wave velocity in Escúzar calcarenite was grater than the velocity measured in the La Escribana material, and the standard deviation in these measurements was higher than for the $S$ waves (Table 4). This high value can be attributed to the great textural heterogeneity of this stone, visible to the naked eye. Both calcarenite rocks had moderate to low anisotropy, and higher total than relative anisotropy, especially in the Escúzar variety. Total anisotropy ( $\triangle M p)$ was higher, in turn, in the Escúzar than in the La Escribana rock, with values of 9.2 and 5\%, respectively. Higher total than relative 
y $5 \%$ respectivamente. Valores más elevados de anisotropía total en relación a los de anisotropía relativa indican que la roca posee una anisotropía más marcada en una de las direcciones del espacio, atribuible a una ligera orientación laminar que puede no ser manifiesta macroscópicamente (37). Nuestros resultados revelan que dicha orientación laminar existe en ambas calcarenitas, presentando la roca de Escúzar texturas de orientación o granoclasificación más acusadas que la roca de La Escribana.

Valores similares de anisotropía total fueron obtenidos por Sebastián Pardo y colaboradores (46) en la calcarenita conocida como "Piedra Franca" de Baeza (9,8\%, medida en velocidades de ondas $P$ ). Contrariamente, otras biocalcarenitas explotadas en la provincia de Granada (como la "Piedra Asperón") presentan valores de anisotropía extremadamente bajos, por ejemplo 0,20\% (47). Valores igualmente bajos $(0,27-0,61 \%)$ fueron determinados por Cultrone et al. (48) en calizas compactas del este de Sicilia (Italia).

Por lo que respecta a los travertinos, el de Olivillo presenta velocidades de ondas $\mathrm{P}$ y $\mathrm{S}$ muy homogéneas, con bajas desviaciones, y valores superiores a los medidos en el travertino de Alfacar. Además, la anisotropía total es mayor que la anisotropía relativa, a diferencia del travertino de Alfacar en el que ambos índices son muy parecidos (1,5\% anisotropy values are an indication that a rock has greater anisotropy in one of the three spatial directions, attributable to a slightly laminar orientation that may not be macroscopically detectable (37). The present results showed that such laminar orientation was present in both calcarenite materials, although textural orientation or grain classification was more accentuated in the Escúzar than the La Escribana variety.

Similar total anisotropy values were obtained by Pardo et al. (46) in Piedra Franca calcarenite quarried near Baeza in the Spanish province of Jaén (9.8\% for $P$ waves). Other biocalcarenites quarried in the province of Granada, however (such as Piedra Asperón) have extremely low anisotropy, with values of $\sim 0.20 \%$ (47). Similarly low values $(0.27-0.61 \%)$ were reported by Cultrone et al. (48) in compact limestone in Eastern Sicily, Italy.

Olivillo travertine, in turn, had very homogeneous $P$ and $S$ values, with low standard deviation and higher values than measured in the Alfacar material. Moreover, the total anisotropy was higher than the relative anisotropy in Olivillo, contrasting in this respect with the Alfacar travertine, in which the two indices are very similar (1.5

Tabla 4 / Table 4

Parámetros ultrasónicos $\left(V_{\mathrm{P}}, V_{S}\right)$, constantes de elasticidad dinámica $\left(E_{d}, v_{d}\right)$ y coeficientes de anisotropía total y relativa de las ondas $\mathrm{S}$ y $\mathrm{P}$ según los tres ejes considerados $(\mathrm{x}, \mathrm{y}, \mathrm{z})$.

Ultrasound velocity $\left(V_{P}, V_{S}\right.$, dynamic elasticity constants $\left(E_{d}, v_{d}\right)$ and $S$ and $P$ wave total and relative anisotropy coefficients along the three spatial axes.

\begin{tabular}{|c|c|c|c|c|c|c|c|c|c|c|c|c|c|}
\hline & $\begin{array}{c}\rho_{\text {bulk }} \\
\left(\mathrm{g} / \mathrm{cm}^{3}\right)\end{array}$ & & \multicolumn{2}{|c|}{$V_{P}(m / s)$} & \multicolumn{2}{|c|}{$\mathrm{V}_{\mathrm{s}}(\mathrm{m} / \mathrm{s})$} & \multirow[t]{2}{*}{$V_{\mathrm{p}} / \mathbf{v}_{\mathrm{s}}$} & \multirow[t]{2}{*}{$\begin{array}{c}E_{d} \\
(\mathrm{GPa})\end{array}$} & \multirow[t]{2}{*}{$v_{d}$} & \multirow[t]{2}{*}{$\Delta \mathrm{M}_{\mathrm{P}}(\%)$} & \multirow[t]{2}{*}{$\Delta \mathrm{m}_{\mathrm{P}}(\%)$} & \multirow[t]{2}{*}{$\Delta \mathrm{M}_{\mathrm{S}}(\%)$} & \multirow[t]{2}{*}{$\Delta \mathrm{m}_{\mathrm{s}}(\%)$} \\
\hline $\begin{array}{c}\text { Calcarenitas I } \\
\text { Calcarenite }\end{array}$ & & & & $( \pm 1 \sigma)$ & & $( \pm 1 \sigma)$ & & & & & & & \\
\hline \multirow{3}{*}{ Escúzar } & \multirow{3}{*}{1.86} & $x$ & 3994 & (692) & 2028 & (76) & 1.97 & 20.3 & 0.33 & \multirow{3}{*}{9.2} & \multirow{3}{*}{2.7} & \multirow{3}{*}{2.4} & \multirow{3}{*}{0.5} \\
\hline & & $y$ & 4459 & (613) & 2083 & (114) & 2.14 & 22.0 & 0.36 & & & & \\
\hline & & $z$ & 4342 & $(454)$ & 2072 & $(78)$ & 2.10 & 21.6 & 0.35 & & & & \\
\hline \multirow{3}{*}{ La Escribana* } & \multirow{3}{*}{1.85} & $x$ & 3328 & - & - & - & - & - & - & \multirow{3}{*}{5.0} & \multirow{3}{*}{3.6} & \multirow{3}{*}{ - } & \multirow{3}{*}{ - } \\
\hline & & $y$ & 3566 & - & - & - & - & - & - & & & & \\
\hline & & $z$ & 3441 & - & - & - & - & - & - & & & & \\
\hline \multicolumn{14}{|l|}{$\begin{array}{c}\text { Travertinos / } \\
\text { Travertine }\end{array}$} \\
\hline \multirow{3}{*}{ Olivillo } & \multirow{3}{*}{2.43} & $x$ & 5627 & (95) & 3035 & (29) & 1.85 & 58.0 & 0.29 & \multirow{3}{*}{2.4} & \multirow{3}{*}{0.7} & \multirow{3}{*}{1.8} & \multirow{3}{*}{0.5} \\
\hline & & $y$ & 5787 & (54) & 3100 & $(61)$ & 1.87 & 60.7 & 0.30 & & & & \\
\hline & & $z$ & 5746 & $(87)$ & 3083 & (3) & 1.86 & 60.0 & 0.30 & & & & \\
\hline \multirow{3}{*}{ Alfacar* } & \multirow{3}{*}{1.81} & $x$ & 4571 & - & 2149 & - & 2.13 & 22.7 & 0.36 & \multirow{3}{*}{1.5} & \multirow{3}{*}{1.6} & \multirow{3}{*}{3.2} & \multirow{3}{*}{2.9} \\
\hline & & $y$ & 4679 & - & 2253 & - & 2.08 & 24.8 & 0.35 & & & & \\
\hline & & $z$ & 4603 & - & 2188 & - & 2.10 & 23.5 & 0.35 & & & & \\
\hline
\end{tabular}

Valores presentados son la media y la desviación estándar de 3 medidas. $\rho_{\text {bulk }}$ : densidad aparente; $\mathrm{V}_{\mathrm{p}}$ : velocidad de la onda compresiva; $\mathrm{V}_{\mathrm{S}}$ : velocidad de la onda de cizalla; $\mathrm{E}_{\mathrm{d}}$ : módulo de Young; $v_{\mathrm{d}}$ : coeficiente dinámico de Poisson; $\Delta \mathrm{Mp}$ : coeficiente de anisotropía total; $\Delta \mathrm{mp}$ : coeficiente de anisotropía relativa. / The values shown are the mean of 3 measurements and the respective standard deviation. $\rho_{\text {bulk: }}$ bulk density; $V_{P}$ : compression wave velocity; $V_{S}$ : shear wave velocity; $E_{d}$ : Young's modulus; $v_{d}$ : Poisson's ratio; $\Delta M p$ : total anisotropy coefficient; $\Delta m p:$ relative anisotropy coefficient.

- Valores no disponibles. * Valores tomados de (14) y (16). Los ejes x, y, z están definidos mediante la velocidad mínima, máxima e intermedia, respectivamente. / - Values not available. * Values extracted from (14) and (16). Axes $x, y$ and $z$ are defined in terms of minimum, maximum and intermediate velocity, respectively. 
y $1,6 \%$ respectivamente). Estos resultados indican la existencia de una orientación en la textura del travertino OliviIlo, de hecho observable a simple vista en forma de un bandeado de diferente color inducido por cristales de calcita de diferente tamaño.

Por otra parte, en la roca Olivillo los valores del módulo de Young son homogéneos y muy altos $\left(E_{d} \sim 60 \mathrm{GPa}\right)$ casi triplicando los valores del travertino de Alfacar $\left(E_{d}<\right.$ $25 \mathrm{GPa}$ ). De lo expuesto se deduce que las propiedades físico-mecánicas del travertino Olivillo lo convierten en un material constructivo de buena calidad. No obstante, el hecho de poseer cierta anisotropía condiciona su colocación en obra y deterioro futuro.

\subsection{Colorimetría}

Los parámetros cromáticos de los materiales constructivos dependen esencialmente de sus características composicionales, por ejemplo de la presencia de pequeñas cantidades de óxidos de hierro o manganeso, pero también se ven influenciados por variaciones texturales como pueden ser el tamaño de los poros o la existencia de bandeados (49). La Tabla 5 presenta los parámetros cromáticos de las rocas estudiadas y de las variedades pétreas de las canteras históricas. La Tabla 5 revela que en las calcarenitas los valores de luminosidad ( $\left.L^{*}\right)$ son relativamente similares, no obstante $L^{*}$ es ligeramente inferior en la calcarenita de Escúzar $(90,34 \pm 0,74)$ que en la calcarenita de La Escribana $(97,74 \pm 0,06)$. En cuanto a las coordenadas cromáticas, la calcarenita de Escúzar es más amarilla que la calcarenita de La Escribana con valores de $b^{*}$ respectivamente de 5,42 $\pm 0,07$ y $1,90 \pm 0,96$, pero más verde (valores más negativos de $\left.a^{*}\right)$. Además posee mayor saturación de color $(C=5,45$ $\pm 0,07)$ que la calcarenita de La Escribana $(2,00 \pm 0,83)$.

Los dos travertinos presentan diferencias colorimétricas más acentuadas, especialmente en lo que se refiere a saturación de color $\left(\mathrm{C}^{*}\right)$ y ángulo de matiz o tono $\left(\mathrm{H}^{*}\right)$. Las coordenadas cromáticas a* y b* indican que el travertino Olivillo es más amarillo y rojizo que el travertino de Alfacar, que presenta mayor $C^{*}(C=7.54 \pm 0,45 v s$ $2,02 \pm 1,08$, respectivamente).

La diferencia cromática total $(\Delta \mathrm{E})$ entre ambos travertinos es muy significativa, con un valor de 28,01 . En cambio el contraste cromático entre las calcarenitas es menos acusado $(8,20)$. Estos resultados indican que la sustitución del travertino Alfacar por la variedad Olivillo conllevaría un efecto visual no deseado que comportaría el deterioro estético del monumento (13). Sin embargo, el reemplazamiento de la calcarenita histórica por la variedad Escúzar no supondría un impacto visual tan acusado. Más aún, dicho contraste cromático permitiría la fácil discernibilidad entre ambas, criterio valorado en la selección de piedras de sustitución. and $1.6 \%$, respectively). These findings are indicative of the existence of textural orientation in the Olivillo stone, which is in fact macroscopically visible in the form of the colour banding induced by differently sized calcite crystals.

Moreover, Olivillo rock exhibited homogeneous and very high Young's modulus values $\left(E_{d} \sim 60 \mathrm{GPa}\right)$, which were nearly triple the Alfacar values ( $E_{d}<25 \mathrm{GPa}$ ). The deduction to be drawn from the foregoing is that the physical-mechanical properties of Olivillo travertine make it a high quality construction material. Nonetheless, the presence of anisotropy conditions its durability and onsite placement.

\subsection{Colorimetry}

While the chromatic parameters of construction materials depend essentially on their composition, such as the presence of small amounts of iron or manganese oxide, they are also affected by textural variations such as pore size or the existence of banding (49). The chromatic parameters of the rocks studied and the stone varieties from historic quarries are given in Table 5 . The table shows that while the lightness $\left(L^{*}\right)$ values in the calcarenite stones were fairly similar, the datum for Escúzar (90.34 \pm 0.74 ) was lower than for La Escribana (97.74 \pm 0.06$)$ calcarenite. The former, moreover, was yellower, with a $b^{*}$ value of $5.42 \pm 0.07$ compared to $1.90 \pm 0.96$, and greener (more negative $a^{*}$ values) than La Escribana. Escúzar also exhibited greater colour saturation ( $C=5.45 \pm 0.07$ ) than La Escribana calcarenite (2.00 \pm 0.83$)$.

The travertine stones showed more accentuated colour differences, particularly in terms of saturation $\left(S^{*}\right)$ and hue $\left(H^{*}\right)$. The findings for the chromatic coordinates $a^{*}$ and $b^{*}$ indicated that Olivillo is yellower and more reddish than Alfacar travertine, and has a higher $S^{*}$ value $(S=7.54 \pm 0.45$ vs $2.02 \pm 1.08)$.

The total chromatic difference $(\Delta E)$ between the two travertine stones was highly significant, at 28.01. The contrast between the calcarenite materials was much more moderate (8.20). According to these results, replacing Alfacar with Olivillo travertine would entail undesirable visual effects and a concomitant deterioration of monument aesthetics (13). In contrast, replacing historic calcarenite with the Escúzar variety would not involve such an intense visual impact. More than that, the chromatic contrast would make the two readily distinguishable, which is a highly recommended feature of replacement stone. 
Tabla 5 / Table 5

Parámetros cromáticos: luminosidad $\left(\mathrm{L}^{*}\right)$, coordenadas cromáticas $\left(\mathrm{a}^{*} \mathrm{y} \mathrm{b}^{*}\right)$, saturación del color $\left(\mathrm{C}^{*}\right)$, ángulo de matiz $\left(\mathrm{H}^{*}\right)$ y diferencias de luminosidad $\left.\Delta \mathrm{L}^{*}\right)$, de las coordenadas cromáticas $\left(\Delta \mathrm{a}^{*}\right.$ y $\left.\Delta \mathrm{b}^{*}\right)$, de la cromaticidad $\left(\Delta \mathrm{C}^{*}\right)$ y del color $\left(\Delta \mathrm{E}^{*}\right)$. Chromatic parameters: lightness $\left(L^{*}\right)$, chromatic coordinates $\left(a^{*}\right.$ and $\left.b^{*}\right)$, saturation $\left(S^{*}\right)$, hue $\left(H^{*}\right)$, lightness $\left(\Delta L^{*}\right)$, and chromatic coordinate $\left(\Delta a^{*}\right.$ and $\left.\Delta b^{*}\right)$, saturation $\left(\Delta S^{*}\right)$ and chromatic $\left(\Delta E^{*}\right)$ differences.

\begin{tabular}{|c|c|c|c|c|c|c|c|c|c|c|c|c|c|c|c|}
\hline $\begin{array}{c}\text { Tipo / Stone } \\
\text { type }\end{array}$ & \multicolumn{2}{|c|}{$L^{*}$} & \multicolumn{2}{|c|}{$a^{*}$} & \multicolumn{2}{|c|}{$\mathbf{b}^{*}$} & \multicolumn{2}{|c|}{$\mathrm{C}^{*}$} & \multicolumn{2}{|c|}{$\mathbf{H}^{*}$} & $\Delta \mathrm{L}^{*}$ & $\Delta \mathrm{a}^{*}$ & $\Delta \mathbf{b}^{*}$ & $\Delta \mathbf{C}^{*}$ & $\Delta E^{*}$ \\
\hline \multicolumn{16}{|l|}{$\begin{array}{c}\text { Calcarenitas I } \\
\text { Calcarenite }\end{array}$} \\
\hline Escúzar & 90.34 & \pm 0.74 & -0.6 & \pm 0.01 & 5.42 & \pm 0.07 & 5.45 & \pm 0.07 & 96.29 & \pm 0.09 & & & & & \\
\hline La Escribana & 97.74 & \pm 0.06 & -0.47 & \pm 0.24 & 1.9 & \pm 0.96 & 2 & \pm 0.83 & 108.88 & \pm 17.76 & -7.40 & -0.13 & 3.52 & 3.45 & 8.20 \\
\hline \multicolumn{16}{|l|}{$\begin{array}{c}\text { Travertinos I } \\
\text { Travertine }\end{array}$} \\
\hline Olivillo & 69.78 & \pm 2.18 & 1.83 & \pm 0.30 & 7.31 & \pm 0.33 & 7.54 & \pm 0.45 & 75.92 & \pm 0.56 & & & & & \\
\hline Alfacar & 97.16 & \pm 0.73 & -0.583 & \pm 0.15 & 1.918 & \pm 1.11 & 2.023 & \pm 1.08 & 111.89 & \pm 14.28 & -27.39 & 2.41 & 5.39 & 5.52 & 28.01 \\
\hline
\end{tabular}

$a^{*}$ : componentes rojo-verde; $b^{*}$ : componentes amarillo-azul. $\Delta \mathrm{E}^{*}=\sqrt{ }\left(\Delta \mathrm{L}^{*}\right) 2+\left(\Delta \mathrm{a}^{*}\right) 2+\left(\Delta \mathrm{b}^{*}\right) 2$. / $\mathrm{a}^{*}$ : red-green components; $b^{*}$ : yellow-blue components. $\Delta E^{*}=\sqrt{ }\left(\Delta L^{*}\right) 2+\left(\Delta a^{*}\right) 2+\left(\Delta b^{*}\right) 2$.

\section{CONCLUSIONES}

Se ha realizado la caracterización petrográfica y físicomecánica detallada de dos rocas carbonáticas muy utilizados como material de construcción actual en Andalucía Oriental (España), éstas son, la calcarenita de Escúzar (Granada) y el travertino de Alhama de Almería, con el fin de determinar su calidad técnica e idoneidad como rocas de sustitución en futuras restauraciones del patrimonio arquitectónico. Para ello, los datos obtenidos se cotejaron con los de las rocas históricas usadas ampliamente en monumentos granadinos, como la calcarenita de La Escribana y el travertino de Alfacar (ambas extraídas en Granada).

La piedra de sustitución debe cumplir unos requisitos de compatibilidad e idoneidad con la original, tal que ambas posean similar comportamiento hídrico, resistencia mecánica y aspecto exterior. Un criterio adicional es el de discernibilidad basado en el contraste cromático, y durabilidad (resistencia a procesos de alteración).

Las calcarenitas estudiadas presentan un aspecto externo muy contrastado. La calcarenita de Escúzar se caracteriza por tener cavidades de hasta $2 \mathrm{~cm}$, y tamaños de clastos centimétricos, a diferencia de la calcarenita histórica que presenta tamaños de poros y bioclastos marcadamente más pequeños y homogéneos. La diferencia cromática entre ambas rocas es apreciable a simple vista $(\Delta \mathrm{E}$ de 8,20$)$, pero no marcadamente diferente, aspecto éste de interés por cuanto contribuye a la discernibilidad de la piedra de sustitución en el monumento sin ocasionar un deterioro estético del conjunto.

\section{CONCLUSIONS}

This study addressed the petrographic and physicalmechanical characterization of two carbonate rocks commonly used in construction in Eastern Andalusia, Spain. The two varieties, Escúzar calcarenite and Alhama (or Olivillo) travertine, quarried in the provinces of Granada and Almería, respectively, were examined to determine both their technical quality and their suitability as replacement stone in future restoration work on the architectural heritage. The data obtained were compared with the information on the historic stone widely used in monuments in Granada, namely La Escribana calcarenite and Alfacar travertine (both quarried in Granada).

Replacement stone must meet suitability requirements and be compatible with the original material: the two rocks must exhibit similar hydraulic behaviour, mechanical strength and visible features. Further criteria include durability (resistance to alteration) and sufficient colour contrast to ensure that the original and replacement stones can be distinguished.

The outer appearance of the calcarenite stones compared differed visibly. The Escúzar variety is characterized by vugs of up to $2 \mathrm{~cm}$ in diameter and centimetre-scale clasts, unlike the historic material, which exhibits substantially smaller and more homogeneous pores and bioclasts. The chromatic difference between the two is perceptible to the naked eye $(\Delta E=8.20)$, but not overly accentuated. This is of particular interest, for it contributes to making the replacement stone distinguishable from the original material in the monument with no detriment to the overall aesthetics. 
Por lo que respecta a las características hídricas, frente a la roca histórica de La Escribana la calcarenita de Escúzar presenta mayor porosidad abierta $(31,86 \%$ vs $20,43 \%)$, absorción libre de agua (16,30\% vs 10,96\%) y saturación $(78,36 \%$ vs $73,98 \%)$, siendo la velocidad de ascenso capilar y la succión capilar similares. La heterogeneidad textural de la calcarenita de Escúzar es superior a la de la roca histórica de La Escribana, presentando mayor índice de anisotropía total que relativo. Ello se traduce en la existencia de texturas de orientación que condicionará su durabilidad en función de su ubicación en las estructuras constructivas. Es decir, la elaboración de las piezas de esta roca y su colocación en relación con la orientación de los planos de estratificación determinará la intensidad y morfologías de su deterioro. En restauraciones futuras, en el caso de que la calcarenita de Escúzar sea usada como roca de sustitución de La Escribana, debe considerarse la mayor anisotropía de aquella y su diferente (aunque mínimo) comportamiento hídrico.

En cuanto a los travertinos estudiados, ambos presentan igualmente un aspecto externo muy diferente. La roca Olivillo corresponde a un travertino masivo, con un bandeado de colores claros y oscuros, y tamaños de poros menores que el travertino de Alfacar. Éste se caracteriza por su marcada porosidad muy heterogénea y presencia de coqueras. El contraste cromático total entre ambos travertinos es tan significativa $(\Delta \mathrm{E} \sim 28)$ que la sustitución del travertino histórico por el de Olivillo comportaría un efecto estético no deseado.

El comportamiento hídrico de ambos travertinos es muy diferente, presentando el travertino masivo OliviIlo valores de absorción y desorción libre de agua, y de porosidad abierta $(6,83 \%$ vs 23,7$)$ muy inferiores a los del travertino de Alfacar. Estos resultados, junto con una mayor densidad real, velocidad de ultrasonidos y más elevado módulo de Young que el travertino de Alfacar, hacen de Olivillo una roca de calidad superior. De hecho los resultados de este trabajo revelan que esta roca presenta unas excelentes propiedades mecánicas que la convierte en un material constructivo muy adecuado. No obstante, la existencia de una anisotropía más marcada en una de las direcciones (mayor anisotropía total que relativa), manifiesta a simple vista en forma de un bandeado, anuncian la necesidad de tomar medidas con vistas a su colocación en obra. Los resultados anteriores sugieren que la presencia conjunta de ambos travertinos en intervenciones de restauración no es aconsejable, tanto por el deterioro diferencial que puedan generar, como por la marcada diferencia cromática que puede restar valor estético al conjunto.
Escúzar also has higher effective porosity (31.86\% vs $20.43 \%)$, free water absorption (16.30\% vs $10.96 \%$ ) and saturation (78.36\% vs $73.98 \%$ ) than historic La Escribana calcarenite, while capillary rise and suction are similar in the two materials. Escúzar calcarenite exhibits greater textural heterogeneity than the historic La Escribana rock, and higher total than relative anisotropy. This translates into the existence of textural orientation that conditions its durability, depending on its position when laid. In other words, the hewing and positioning of this rock with respect to the orientation of its stratification planes determine the intensity and morphology of its deterioration. If Escúzar calcarenite is to be used in future restorations as a replacement stone for the La Escribana variety, account should be taken of its greater anisotropy and (minimally) different hydraulic behaviour.

The outer appearance of the two travertine stones compared differs substantially. Olivillo is a massive travertine, with light and dark colour banding and smaller pore sizes than in the Alfacar rock. The latter is characterized by significant and very heterogeneous porosity and the presence of vugs. The chromatic contrast between these two materials is so accentuated $(\Delta E \sim 28)$ that replacing the historic travertine with Olivillo would entail an undesirable aesthetic effect.

The hydraulic behaviour of the two stones likewise differs substantially, with the massive Olivillo exhibiting much lower free water absorption and desorption and effective porosity $(6.83 \%$ vs $23.7 \%$ ) values than the Alfacar variety. These findings, along with greater real density, ultrasound velocity and a higher Young's modulus in the Olivillo stone than in the historic Alfacar travertine denote the higher quality of the former. Further to such findings, the excellent mechanical properties of this rock make it a highly suitable construction material. Nonetheless, the presence of more accentuated anisotropy in one spatial direction (greater total than relative anisotropy), visible to the naked eye in the form of banding, is indicative of the need to take special on-site measures when it is laid. The foregoing suggests that the joint presence of the two travertine stones in restoration works is not advisable, in light of both the differential deterioration this would entail and the accentuated chromatic difference that would detract from the aesthetic value of the monument as a whole. 


\section{AGRADECIMIENTOS}

Este trabajo ha sido financiado por el Grupo de Investigación RNM-179 y el Proyecto de Investigación de Excelencia FQM-1633, ambos de la Junta de Andalucía. M. Urosevic posee una beca del Ministerio de Innovación Ciencia y Tecnología (AP2006-060).

\section{ACKNOWLEDGMENTS}

This study was funded by Research Group RNM-179 and Research Excellence Project FQM-1633, both under the aegis of the Regional Government of Andalusia. M. Urosevic participated under a Spanish Ministry of Innovation, Science and Technology grant (AP2006-060).

\section{BIBLIOGRAFÍA / BIBLIOGRAPHY}

(1) Cantó, A. M.: "Avances sobre la explotación del mármol en la España romana", Archivo Español de Arqueología, vol. 50-51 (19771978), pp. 165-188.

(2) Beltrán Fortes, J.: "Expertos universitarios investigan el uso de los marmora en la Bética romana", PH Boletín del Instituto Andaluz del Patrimonio Histórico, vol. 59, (2006), pp. 4-17.

(3) Sebastián, E.; Zezza, U.; Rodríguez-Navarro, C.; De la Torre, M. J.; Cardell, C.: "La Piedra Franca, biocalcarenita, en la construcción de edificios históricos de Granada", I Congreso Internacional Rehabilitación del Patrimonio Histórico y Edificación (1992), Islas Canarias, Spain, pp. 329-336.

(4) Birginie, J. M.; Rivas, T.; Prieto, B.; Auger, F.: "Comparación de la resistencia a la alteración por niebla salina de dos calizas utilizadas en la construcción mediante métodos ponderales, métodos acústicos y tratamiento de imágenes", Materiales de Construcción, vol. 50, no 259 (2000), pp. 27-43. doi:10.3989/mc.2000.v50.i259.397

(5) Arizzi, A.; Belfiore, C. M.; Cultrone, G.; Rodríguez-Navarro, C.; Sebastián Pardo, E.; Triscari, M.: "Petro-chemical and physical investigations on the 'Santa Pudia Calcarenite' (Andalusia, Spain): New hints for the prevention and conservation of calcarenitic building materials", Goldschmidt Conference Abstracts, A35 (2007).

(6) Buj, O.; Gisbert, J.: "Caracterización petrofísica de tres variedades comerciales de areniscas miocenas del valle del Ebro", Materiales de Construcción, vol. 57, no 287 (2007), pp. 63-74.

(7) Luque, A.; Cultrone G.; Sebastián, E.; Cazalla, O.: "Evaluación de la eficacia de tratamientos en el incremento de la durabilidad de una calcarenia bioclática (Granada, España)", Materiales de Construcción, vol. 58, no 292 (2008), pp. 115-128.

(8) Martínez-Martínez, J.: "Influencia de la alteración sobre las propiedades mecánicas de calizas, dolomías y mármoles. Evaluación mediante estimadores no destructivos (ultrasonidos)", Tesis Doctoral, Universidad de Alicante (2008).

(9) Sebastián Pardo, E.; Cultrone, G.; Garibaldi, V.; Rodriguez Navarro, C; de la Torre, M. J.; Valverde, I.: "The Sierra Elvira limestone: petrophysical features of a widespread Andalusian decorative material", Materiales de Construcción, vol. 58, no 289-290 (2008), pp. 51-63.

(10) Cueto, N.; Benavente, D.; Martínez-Martínez, J.; García del Cura, M. A.: "Rock fabric, pore geometry and mineralogy effects on water transport in fractured dolostones", Engineering Geology, vol. 107, no 1-2 (2009), pp. 1-15. doi:10.1016/j.enggeo.2009.03.009

(11) Sáez Pérez, M. P.: "Estudio de elementos arquitectónicos y composición de materiales del Patio de los Leones. Interacciones en sus causas de deterioro", Tesis Doctoral, Universidad de Granada (2003).

(12) Barrios Neira, J.; Montealegre, L.; Ortega, A.; Meroño, J. E.; Aguilera, M. J.: "Biocalcarenites as construction materials in Santa Marina de Aguas Santas church at Cordoba, Spain", Materiales de Construcción, vol. 59, no 293 (2009), pp.125-134.

(13) Fort González, R.: "Utilización de la piedra natural en restauración", Seminarios de la Sociedad Española de Mineralogía, vol. 2 (2005), pp. 155-182.

(14) Rodríguez-Navarro, C.: "Causas y mecanismos de alteración de los materiales calcáreos de las catedrales de Granada y Jaén", Tesis Doctoral, Universidad de Granada (1994).

(15) Cardell, C.: "Cristalización de sales en calcarenitas. Aplicación al Monasterio de San Jerónimo", Tesis Doctoral, Departamento de Mineralogía y Petrología, Universidad de Granada (1998).

(16) Rodríguez-Navarro, C.; Sebastián-Pardo, E.; Ruiz-Agudo, E: "Plan Director del Hospital Real: Estudio de materiales, formas y mecanismos de alteración", informe interno, Universidad de Granada (2008).

(17) Guardia Olmedo, J.; Gómez Moreno, J. M.; López Guzmán, R.; Prieto Moreno, J.: "Arte y deterioro en los monumentos granadinos. Catedral, Chancillería y Palacio de Carlos V", Universidad de Granada, Junta de Andalucía (1986).

(18) Durán-Suárez, J. A.; García-Casco, A.; Sánchez-Navas, A.; Rodríguez-Gordillo, J.: "Caracterización de las alteraciones en pilares de travertino de la Iglesia del Salvador (Granada). Propuestas restauradoras", Boletín de la Sociedad Española de Mineralogía, vol. 16 (1993), pp. 1-12.

(19) Cardell-Fernández, C.; Rodríguez-Gordillo, J.: "A comparative study of calcarenite salt crystallisation and weathering in laboratory conditions and in a monument", 8th International Conference on Non Destructive Investigations and Microanalysis for the Diagnostics and Conservation of the Cultural and Environmental Heritage, Lecce, Italy (2005). 
(20) Velilla Sánchez, N.: "Caracterización petrográfica de rocas ornamentales y de construcción de uso en los edificios históricos", Metodología de diagnóstico y evaluación de tratamientos para la conservación de los edificios históricos (Cuadernos técnicos), Junta de Andalucía (2003), pp. 22-35.

(21) Ruiz-Agudo, E.: "Prevención del daño debido a la cristalización de sales mediante el uso de inhibidores de la cristalización", Tesis Doctoral, Universidad de Granada (2007).

(22) Cardell, C.; Benavente, D.; Rodríguez-Gordillo, J.: "Weathering of limestone building material by mixed sulfate solutions. Characterization of stone microstructure, reaction products and decay forms", Materials Characterization, vol. 59, no 10 (2008), pp. 1371-1385. doi:10.1016/j.matchar.2007.12.003

(23) www.loslinos.es

(24) García del Cura, M. A.; Sanz-Montero, E.; Benavente, D.; Martínez-Martínez, J.; Bernabéu, A.; Cueto N: "Sistemas travertínicos de Alhama de Almería: características petrográficas y petrofísicas", Geotemas, vol. 10 (2008), pp. 456-459.

(25) Voersman, F.; Baena, J.: Mapa geológico de España escala 1:50.000. Hoja 1.044 Alhama de Almería, Mapa y Memoria, IGME, Madrid (1983).

(26) García del Cura, M. A.; La Iglesia, A.; Ordóñez, S.; Sanz-Montero, E.; Benavente, D: "Óxidos de hierro y manganeso en travertinos de Alhama de Almería", Macla, vol. 9 (2008), pp. 107.

(27) www.marmolesnevado.es

(28) Martín Ramos, J. D.: XPowder. A software package for powder X-ray diffraction analysis, Lgl. Dep. GR 1001/04, Granada (2004).

(29) Sing, K. S. W.; Everett, D. H.; Haul, R. A. W.; Moscou, L.; Pierotti, R. A.; Rouquérol, J.; Siemieniewska, T.: "Reporting Physisorption Data for Gas/Solid Systems", Pure and Applied Chemistry (IUPAC), vol. 57 (1985), pp. 603-619. doi:10.1351/pac198557040603

(30) Gregg, S. J.; Sing, K. S. W.: Adsorption Surface Area and Porosity, Academic Press, London (1982).

(31) Adamson, A. W.; Gast, A. P.: Physical Chemistry of Surfaces, J. Wiley \& Sons, New York (1997).

(32) Barret, E. P.; Joyner, L. G.; Halenda, P. P.: "The Determination of Pore Volume and Area Distributions in Porous Substances. I. Computations From Nitrogen Isotherms", Journal of the American Chemical Society, vol. 73 (1951), pp. 373-380. doi:10.1021/ja01145a126

(33) Tang, P.; Chew, N. J. K.; Chan, H-K.; Raper, J. A.: "Limitation of determination of surface fractal dimension using N2 adsorption isotherms and modified Frenkel-Halsey-Hill theory", Langmuir, vol. 19 (2003), pp. 2632-2638. doi:10.1021/la0263716

(34) UNE-EN 1925: Método de ensayo para piedra natural. Determinación del coeficiente de absorción de agua por capilaridad, AENOR, Madrid (1999).

(35) UNE-EN 13755: Método de ensayo para piedra natural. Determinación de la absorción de agua a presión atmosférica, AENOR, Madrid (2002).

(36) RILEM: Recommended test to measure the deterioration of stone and to assess the effectiveness of treatment methods, Commision 25-pem: Protection et Erosion des Monuments (1980), pp. 175-253.

(37) Fort, R.; Fernández-Revuelta, B.; Varas, M. J.; Álvarez de Buergo, M.; Taborda-Duarte, M.: "Influencia de la anisotropía en la durabilidad de las dolomías cretácicas de la Comunidad de Madrid frente a la cristalización de sales", Materiales de Construcción, vol. 58, no 289-290 (2008), pp. 161-178. doi:10.3989/mc.2008.v58.i289-290.74

(38) Wyszecki, G.; Stiles, W. S.: Colour Science. Concepts and Methods, Quantitative Data and Formulae (2nd Edition), J. Wiley \& Sons, New York (1982).

(39) Ruiz-Agudo, E.; Mees, F.; Jacobs, P.; Rodríguez-Navarro, C.: "The role of saline solution properties on porous limestone salt weathering by magnesium and sodium sulfates", Environmental Geology, vol. 52 (2007), pp. 269-281. doi:10.1007/s00254-006-0476-x (40) Pérez Bernal, J. L.; Bello López, M. A.: "The fractal dimension of stone pore surface as weathering descriptor", Applied Surface Science, vol. 161 (2000), pp. 47-53. doi:10.1016/S0169-4332(00)00031-3

(41) Urosevic, M.; Sebastián Pardo, E.; Cardell, C.: "Rough and polished travertine building stone decay evaluated by a marine aerosol ageing test", Construction and Building Materials (2010). doi:10.1016/j.conbuildmat.2010.01.011

(42) Cultrone, G.: "Stone deterioration and conservation treatments in Cultural Heritage", Marie Curie Fellowship of the European Community Programme "Energy, Environment and Sustainable Development", Universidad de Granada (2004).

(43) Karaca, Z.: "Water absorption and dehydration of natural stones versus time", Construction and Building Materials, (2009). doi 10.1016/j.conbuildmat.2009.10.029

(44) Martínez-Martínez, J.; Benavente, D.; Ordóñez, S.; García del Cura, M. A.: "Multivariate statistical techniques for evaluating the effects of brecciated rock fabric on ultrasonic waves propagation", International Journal of Rock Mechanics and Mining Sciences, vol. 45 (2008), pp. 609-620. doi:10.1016/j.jirmms.2007.07.021

(45) Sáez Pérez, M. P.; Rodríguez-Gordillo, J.: "Structural and compositional anisotropy in Macael marble (Spain) by ultrasonic, XRD and optical microscopy methods", Construction and Building Materials, vol. 23, no 6 (2009), pp. 2121-2126. doi:10.1016/j.conbuildmat.2008.10.013

(46) Sebastián Pardo, E.; Martín Clavo, J.; Zezza, U.: "The "Piedra Dorada" calcarenite in the cultural built heritage of Baeza (andalusian province of Jaen, Spain)", Atti Ticinesi di Scienze della Terra, vol. 38 (1995), pp. 205-213. 
(47) Sebastián Pardo, E.; De la Torre, M. J.; Cazalla, O.; Cultrone, G.; Rodríguez-Navarro, C.: "Evaluation of treatments on biocalcarenites with ultrasound", The e- Journal of Nondestructive Testing \& Ultrasonics, vol. 4, no 12 (1999).

(48) Cultrone, G.; Russo, L. G.; Calabrò, C.; Urosevic, M.; Pezzino, A.: "Influence of pore system characteristics on limestone vulnerability: a laboratory study", Environmental Geology, vol. 54 (2008), pp. 1271-1281. doi:10.1007/s00254-007-0909-1

(49) Gökay, M. K.; Gundogdu, I. B.: "Color identification of some Turkish marbles", Construction and Building Materials, vol. 22, no 7 (2008), pp. 1342-1349. doi:10.1016/j.conbuildmat.2007.04.016 